\title{
The Status and Challenges of Replicating the Mechanical Properties of Connective Tissues using Additive Manufacturing
}

Saeed Miramini (Corresponding author)

Department of Infrastructure Engineering, The University of Melbourne, Victoria 3010, Australia

Email: s.miramini@unimelb.edu.au

Tel: +(613) 83449696; Fax: +(613) 83444616;

Katie L. Fegan

Department of Mechanical Engineering, School of Engineering, University of Birmingham, Edgbaston, Birmingham, B15 2TT, UK

Email: K.Fegan@pgr.bham.ac.uk

Naomi C. Green

Department of Mechanical Engineering, School of Engineering, University of Birmingham, Edgbaston, Birmingham, B15 2TT, UK

Email: N.C.Green@bham.ac.uk

Daniel M. Espino

Department of Mechanical Engineering, School of Engineering, University of Birmingham, Edgbaston, Birmingham, B15 2TT, UK

Email: D.M.Espino@bham.ac.uk

\section{Lihai Zhang}

Department of Infrastructure Engineering, The University of Melbourne, Victoria 3010, Australia

Email: lihzhang@unimelb.edu.au

Lauren E. J. Thomas-Seale

Department of Mechanical Engineering, School of Engineering, University of Birmingham, Edgbaston, Birmingham, B15 2TT, UK

Email: L.E.J.Thomas-Seale@bham.ac.uk 


\begin{abstract}
The ability to fabricate complex structures via precise and heterogeneous deposition of biomaterials makes additive manufacturing (AM) a leading technology in the creation of implants and tissue engineered scaffolds. Connective tissues (CTs) remain attractive targets for manufacturing due to their "simple" tissue compositions that, in theory, are replicable through choice of biomaterial(s) and implant microarchitecture. Nevertheless, characterisation of the mechanical and biological functions of 3D printed constructs with respect to their host tissues is often limited and remains a restriction towards their translation into clinical practice. This review aims to provide an update on the current status of AM to mimic the mechanical properties of CTs, with focus on arterial tissue, articular cartilage and bone, from the perspective of printing platforms, biomaterial properties, and topological design. Furthermore, the grand challenges associated with the AM of CT replacements and their subsequent regulatory requirements are discussed to aid further development of reliable and effective implants.
\end{abstract}

Keywords: 3D Printing; Biomaterial Characterisation; Design; Tissue Engineering Scaffolds; Implants; Bioprinting

\title{
1. Introduction
}

The application of additive manufacturing (AM), also known as 3D printing, has become increasingly attractive in the medical implant industry. Fabrication of implants and tissue substitutes using AM offers several advantages over traditional, top-down tissue engineered scaffolds, such as precise patient-specific and optimised microarchitecture design, composite and bioprinting capability, relatively faster fabrication, and increased cost efficiency. This is particularly important in the production of small-scale products such as patient-specific implants. However, there are several challenges involved in the fabrication of tissue substitutes using AM. Tissue is a complex biological composite and it is imperative that $\mathrm{AM}$ constructs mimic the tissue 3D microarchitecture and microenvironment to convey the native function.

Of the four primary classes of tissue, connective tissue (CT) is the simplest tissue to 3D print. Unlike epithelial, nerve and muscle tissue, CTs are characterised by a vast volume of extracellular matrix (ECM) and a relatively low number of cells (Ombregt, 2013). This property gives rise to two main functions. Firstly, the ECM, a dynamic network of collagen and elastin fibrils embedded within an amorphous interfibrillar matrix known as ground substance, provides the body with both form and support through distribution of mechanical stresses. Secondly, the ground substance serves as a transportation route for CT cells. The activities of CT cells rely on mechanotransduction, the concept of converting mechanical stimuli to elicit a biological response, to function (Orr et al., 2006; Tomasek et al., 2002; Zhang et al., 2017a). Graft failure due to compliance mismatch between synthetic implants and host tissue is well documented (Inoguchi et al., 2006; Mitchell and Niklason, 2003; Yoder and 
Elliott, 2010). Therefore, AM biomaterials must mimic the mechanical properties of healthy CT if they are to facilitate cellular activities.

CT is classified according to the composition of the ECM (Stecco, 2014). Consequently, three major subgroups are defined: (1) CT proper (loose CT, dense CT), (2) specialised CT (cartilage, bone, adipose), and (3) fluid CT (blood, lymphatic). For the purpose of this review, fluid CT shall be excluded. The mechanical and biological requirements of CT replacements differ widely according to the tissue of interest, and this is reflected in the most representative choice of AM biomaterial. Here, the following case study tissues shall be used: arterial (coronary, aorta, and femoral), articular cartilage, and bone (cortical and cancellous).

In assessing the most "representative" choice of biomaterial, the function of the implant is considered. Implants may be non-biodegradable, serving as permanent CT supports or replacements, or biodegradable, acting as temporary scaffolds for CT regeneration and reconstruction. Both permanent and biodegradable implants are discussed in this review. In both cases, the mechanical biocompatibility of the implant with respect to the tissue of interest is critical. This has, to some degree, been summarised in recent reviews. For instance, Mazza and Ehret (2015) reviewed the deformation behaviour of soft tissue replacements, with focus on prosthetic meshes for hernia and pelvic repair, in tandem with macro- and microscale deformation of native tissue. However, a similar review has not been conducted for 3D printed tissue replacements, where printing platform and geometric design additionally influence the mechanical performance of the implant. Furthermore, whilst the mechanical characterisation of AM polymer parts has been discussed at length by Dizon et al. (2018), mechanical characterisation of 3D printed biomaterials remains in its infancy. As the volume of literature surrounding AM in CT engineering increases, the need for a review of the AM platforms and biomaterials available for CT replacement, and the testing methods used to characterise mechanical biocompatibility, becomes evident.

This review therefore aims to provide the following: (1) an overview of the biomechanics of CT, compiling quantitative data on the mechanical characterisation of arterial, articular cartilage and bone tissue; and (2) a summary of the current status of mechanical and structural characterisation of AM biomaterials with respect to (1). Specifically, the impact of biocompatibility and printability of biomaterials, as well as the topological design constraints afforded by AM, is explored. In addition, a commentary on the commercialisation and regulatory issues surrounding AM devices is provided. In doing so, this paper shall identify key limitations of existing AM processes and highlight the future opportunities that AM offers to replicate materials which exhibit the properties of CT more accurately.

\section{Compatible AM Platforms for Connective Tissue Replacement}

Regardless of the biomaterial used, AM involves three main stages (Dawood et al., 2015). Firstly, the macro- and microarchitecture of the tissue replacement is designed using CAD-CAM/FEM software, based on the patient specific data and the characteristic requirements of the tissue. Next, the tissue replacement is printed layer-by-layer using a suitable AM platform and biomaterial. Finally, the 3D printed material is post-processed and prepared for implantation. As summarised in Table 1, several AM techniques exist for tissue engineering depending on the type and nature of the biomaterial and whether stem cells 
(bioinks) are incorporated into the scaffold. This section briefly summarises different AM techniques for tissue engineering applications. Specifically, their benefits, drawbacks, and challenges with respect to replicating CT is discussed.

\subsection{Material Extrusion Techniques (MET)}

\section{Fused Deposition Modelling (FDM)}

As the most common AM technique, fused deposition modelling (FDM) heats up a filament of a thermoplastic polymer to the semi-liquid state, extruding and depositing it in layers on a printing platform (Fig. 1.a). In this way, the layers are fused and solidified (Dawood et al., 2015). Thermoplastic polymers, including biodegradable polymers such as polylactic acid (PLA) and polycaprolactone (PCL), can be 3D printed using this technique (Cao et al., 2003; Hsu et al., 2007). Biodegradable vascular stents have been produced using these materials (Guerra et al., 2018). An advanced, high-resolution FDM printer is essential for fabrication of scaffolds with small pore size, high surface quality, and consistent mechanical properties. This method is also known as precision extruding deposition (PED) within the field of tissue engineering (Shor et al., 2009).

Due to the high temperatures required for extrusion, FDM cannot process bioinks (i.e. polymers imbedded with cells or growth factors) (Miar et al., 2018). In addition, as thermoplastic resins are intrinsically of low stiffness, printing of thermoplastic polymers using FDM has limited application in the manufacturing of load bearing constructs such as bone fracture implants. However, by incorporating a continuous fibre in the thermoplastic filament of the printer, a fibre-reinforced polymer scaffold can be constructed with enhanced stiffness and strength (Matsuzaki et al., 2016). Alternatively, particle reinforced polymer-ceramic composites can be created (Kalita et al., 2003). FDM is also suitable for producing pure bioceramics for bone grafts or dental implants through the integration of high concentrations of fine ceramic powders into a thermoplastic binder to create a powder binder filament. Following printing, the fabricated object should undergo binder removal and sintering to form a solid ceramic, similar to ceramic injection moulding processes (Chen et al., 2018).

\section{Direct Ink Writing (DIW)}

Direct ink writing (DIW), also known as robocasting, 3D plotting or microextrusion, deposits a continuous strand of viscous material onto a printer bed via a robotically controlled extrusion nozzle. Printing is normally operated at room or physiologically safe temperature and does not involve the high temperatures required in FDM. As illustrated in Fig. 1.b, material extrusion is carried out by a pneumatically or mechanically pressurized dispensing system, which enables material flow under extrusion pressure (Murphy and Atala, 2014b). Thus, the rheological properties of the printing material can greatly affect the printing process and shape of the final product. Printable materials typically have a viscosity in the range of $30 \mathrm{mPa} / \mathrm{s}$ to $6 \times 10^{7} \mathrm{mPa} / \mathrm{s}$ (Jones, 2012). Shear thinning materials are particularly suitable for DIW, as they readily flow and extrude under high shear stress through the printer nozzle and solidify after printing. The deposited material may need to be further crosslinked through chemical or photoinduced means, but this can slow down the printing process (Skardal et al., 2010).

DIW-printable materials include synthetic and natural hydrogels (Ghosh et al., 2008). Furthermore, hydrogels can be loaded with cells and printed using DIW in a technique known as 3D bioplotting. Cell viability is highly affected by printer nozzle size and extrusion pressure. 
Although cell viability can be improved by increasing nozzle size and reducing extrusion pressure, printing resolution and speed is compromised. A printing resolution of $5 \mu \mathrm{m}-1 \mathrm{~mm}$ can be achieved when printing bioinks (Murphy and Atala, 2014b). Different CTs have been fabricated using 3D bioplotting, including aortic valve (Duan et al., 2013) and articular cartilage (You et al., 2017). Microextrusion-based bioprinting has been reviewed in detail by Ozbolat and Hospodiuk (2016).

DIW can be also used for fabrication of bioceramics. In brief, extrusion of a highly viscous ceramic paste, or slurry, with small organic content is printed at room temperature. The printed object should be pyrolysed and sintered for debinding of the organic content and consolidation to form a solid ceramic (Chen et al., 2018).

\section{Material Extrusion Techniques}

(a) Fused Deposition Modelling (FDM)

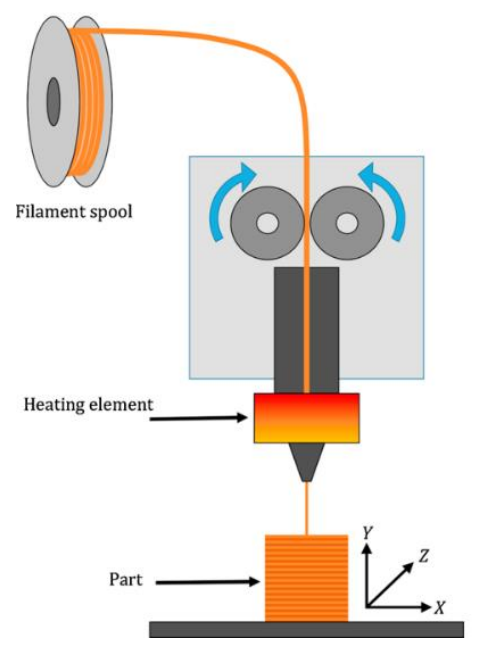

(b) Direct Ink Writing (DIW)

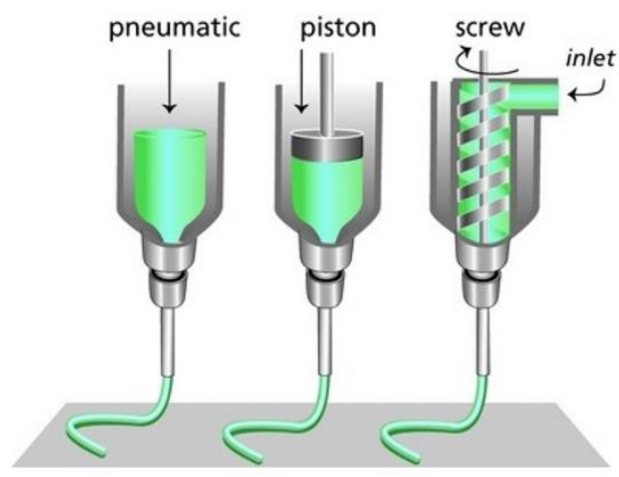

Fig. 1. Schematic of material extrusion techniques: (a) Fused Deposition Modelling (FDM) and (b) Direct Ink Writing also known as microextrusion, robocasting or 3D plotting. Figures adapted with permission from (Stansbury and Idacavage, 2016), Elsevier and (Malda et al., 2013), John Wiley \& Sons respectively.

\subsection{Lithography-based AM}

\section{Stereolithography (SLA)}

As one of the founding AM techniques, stereolithography (SLA) uses UV light to spatially polymerise single layers of liquid photo-crosslinkable resin. After each layer is processed and patterned, another layer of liquid resin is spread and the process is repeated (Fig. 2.a). The unpolymerised resin is then drained and removed at the end of the printing process. The printed part is post-processed in a UV oven to ensure polymerisation of the untreated parts and strengthening of the entire structure. SLA has a very small resolution $(\sim 1.2 \mu \mathrm{m})$ and exceptional accuracy, and is therefore capable of manufacturing objects with complex internal architecture (Zhang et al., 1999). However, due to the scarcity of biocompatible photocurable resins and weak mechanical strength of photopolymerised resins (Chia and $\mathrm{Wu}, 2015$ ) it has limited application in CT engineering. Nevertheless, new compatible resins with improved 
mechanical properties after polymerisation are being developed to overcome these limitations (Melchels et al., 2010b). SLA has been utilised in several studies to fabricate CT scaffolds from biodegradable synthetic polymers, including poly(propylene fumarate) (PPF) (Lee et al., 2007), photocrosslinkable PCL (Elomaa et al., 2011), poly(trimethylene carbonate) (PTMC) (Schüller-Ravoo et al., 2013), and poly(D,L-lactide) (PDLLA) (Melchels et al., 2010a).

In addition, SLA can be used to manufacture hydrogel-based scaffolds from photocrosslinkable hydrogels. Furthermore, photoencapsulated bioinks using SLA demonstrate improved cell concentration and homogeneity (Arcaute et al., 2010; Arcaute et al., 2006; Chan et al., 2010; Lee et al., 2008; Seck et al., 2010). To improve the mechanical strength of the fabricated scaffold, photocrosslinkable resins can be mixed with micro- or nanosized bioceramics such as hydroxyapatite (HA) (Ronca et al., 2013). It is also possible to manufacture pure bioceramic constructs by mixing a high concentration of bioceramic powder with the resin before printing (Skoog et al., 2014).

\section{Digital Light Processing (DLP)}

Analogous to SLA, digital light processing (DLP) relies on photopolymerisation for AM. However, in SLA, a robotically controlled UV laser rasters across the printer platform to crosslink the resin, whereas in DLP, the cross-sectional image of each layer is projected using a UV light projector (see Fig. 2). DLP can achieve faster printing as each layer is immediately crosslinked, but the trade-off is poorer resolution, which negatively impacts surface finish and fine features. The technique has been used to fabricate bone scaffolds from biodegradable polymers (Dean et al., 2014; Dean et al., 2012) as well as from bioceramics such as HA (Zeng et al., 2018). In addition, DLP has been used to print a bioink produced from methacrylated silk fibroin (Kim et al., 2018).

\section{Photopolymerisation 3D Printing}

(a) Stereolithography (SLA)

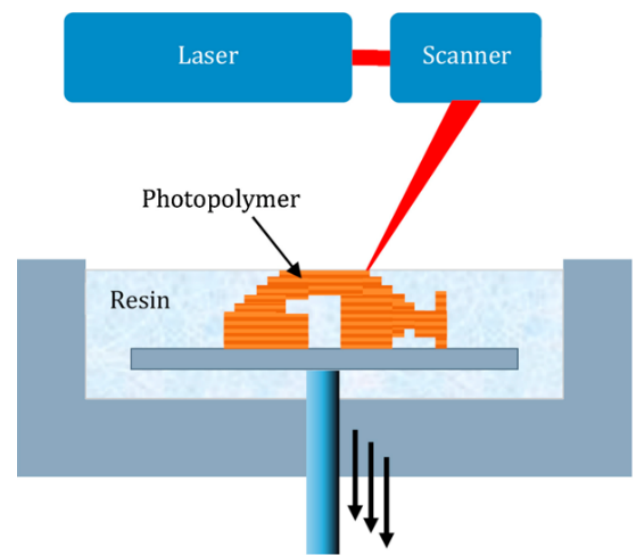

(b) Digital Light Processing (DLP)

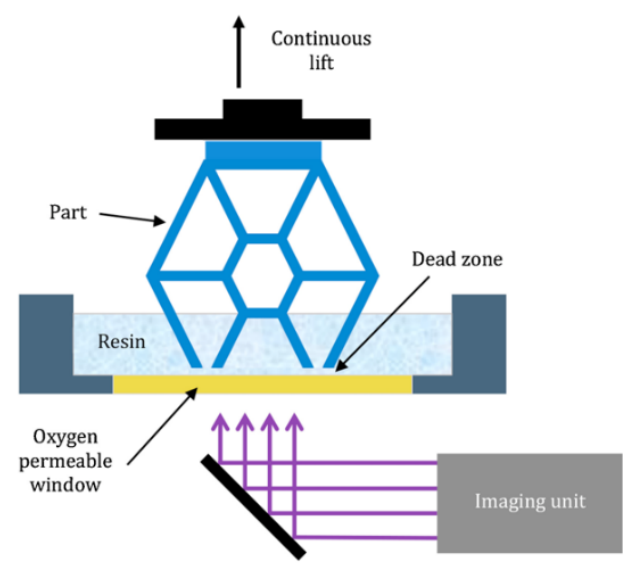

Fig. 2. Schematic diagram of lithography-based AM: (a) Stereolithography (SLA) and (b) Digital Light Processing (DLP). Figures adapted from (Stansbury and Idacavage, 2016) with permission from Elsevier. 


\subsection{Powder Bed Fusion (PBF)}

In powder bed fusion (PBF) platforms, a high energy beam is used to fuse fine grains of powdered material, densely packed on the printer bed, into a desired pattern (Fig. 3). The unused powder serves as a support for the structure during printing and is subsequently recycled after the object is formed. Therefore, compared to lithography-based AM techniques, no additional support material is needed. Several PBF-based 3D printers are available and characterised by the fusion process.

\section{Selective Laser Sintering (SLS)}

Selective laser sintering (SLS) uses a high energy laser to fuse powder at the molecular level (i.e. sintering). Therefore, any material available in powder form with sintering capability is suitable for processing. This includes metals and alloys, as well as a range of polymers, ceramics, and composite materials (Kruth et al., 2003). SLS can process polymer powders with high melting points, thus SLS-fabricated polymers have superior mechanical properties (Dawood et al., 2015). The quality of the printed part is largely dependent on printing parameters such as laser power and speed, powder size and composition, and powder layer thickness (Mohamed et al., 2015). In addition, post-processing such as post sintering, heat treatment, and material infiltration is often required to further improve the mechanical properties (Yap et al., 2015).

Customised bone scaffolds are producible using SLS. Common biocompatible materials for SLS include metals such as titanium alloy (Ti-6Al-4V) and cobalt chromium molybdenum alloy (Co-Cr-Mo) as well as biocompatible polymers such as polyetheretherketone (PEEK) (Bertol et al., 2010; Elsayed et al., 2019; Vandenbroucke and Kruth, 2007). SLS can also be used to fabricate polymer-bioceramic scaffolds, in which the polymer forms the matrix and the bioceramic particles impact reinforcement and biointegration capacity (Babilotte et al., 2019). Bioceramic scaffolds are also manufacturable through the addition of low melting point polymer or glass powder to the bioceramic powder. By serving as a liquid-phase binder, the ceramic sintering process is improved (Chen et al., 2018). The polymeric/glass component is decomposed and eliminated during the laser sintering process. Meanwhile, the bioceramic particles bond and fuse (Gao et al., 2013). 


\section{Powder Bed Fusion (PBF)}

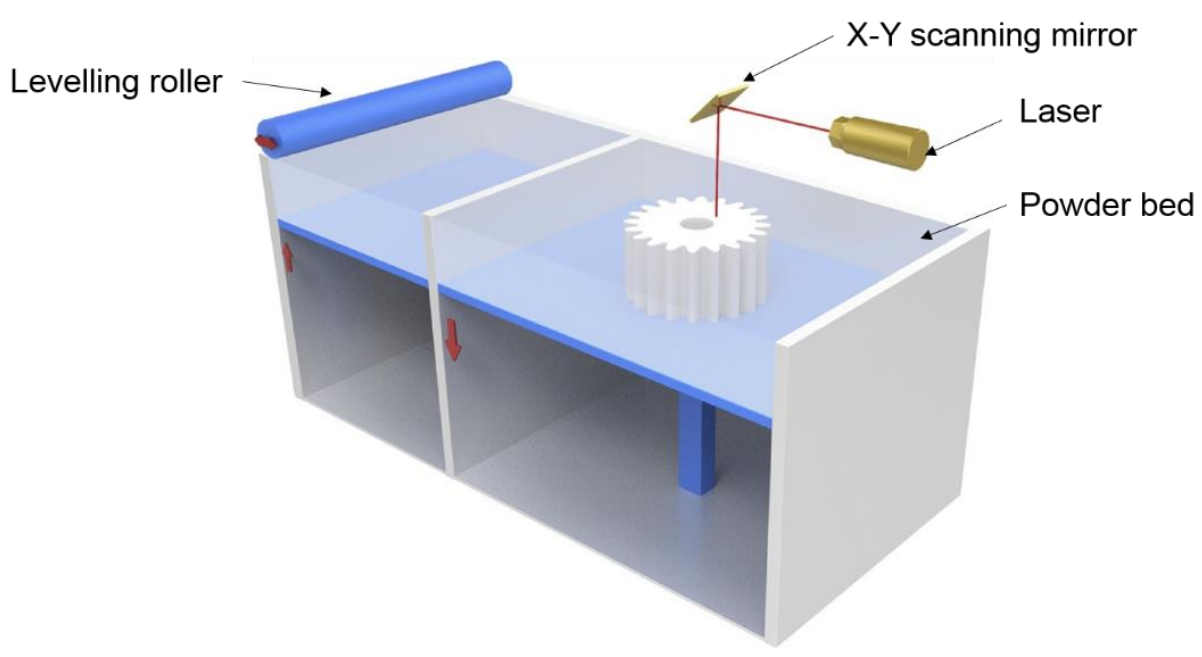

Fig. 3. Schematic of powder bed fusion technique. Figure reproduced with permission from Elsevier (Chen et al., 2018)

\section{Selective Laser Melting (SLM)}

Selective laser melting (SLM) and electron beam melting (EBM) are one-step PBF techniques that use a high energy density laser and electron beam respectively to fully melt material powder to form a dense and homogeneous object. This technique is widely used to generate 3D printed metals with enhanced mechanical properties. Similar to SLS, the mechanical strength of SLM-fabricated metals is highly influenced by printing parameters, notably laser power, scanning speed, powder size, and powder layer thickness. Through control of these parameters, porous titanium implants with structures comparable to human cancellous bone are manufacturable (Pattanayak et al., 2011). However, the laser power must be carefully considered. While a small laser energy density results in insufficient fusion and balling effect, too large energy densityleads to vaporization of metal powder. Both cases negatively impact the mechanical properties of the object (Jaber and Kovacs, 2019).

\subsection{Inkjet printing}

\section{Droplet-Based Printing (DBP)}

Droplet-based printing (DBP), or material jetting, is one of the most commonly used AM techniques in tissue engineering. As shown in Fig. 4.a material inkjet printers apply thermal energy or acoustic radiation to eject droplets of the printing material and deposit them 
on the printing bed, layer-by-layer, thereby fabricating the 3D object. The technique can be used for printing both non-biological and biological materials. The printing material should be in semi-liquid state to form the droplets. The printed material may need to be crosslinked optically, chemically, or thermally following deposition (Khalil and Sun, 2007; Murphy et al., 2013).

DBP has been widely used for bioink printing. Nevertheless, the heat and pressure applied to the bioink during droplet ejection may influence cell viability and functionality. It has been shown that the thermal energy applied to the bioink during ejection can heat the cells up to $46^{\circ} \mathrm{C}$ for $2 \mu \mathrm{s}$. However, no significant cell apoptosis is observed when printing is carried out at room temperature (Cui et al., 2010). Non-uniform droplet size and frequent nozzle clogging also pose issues with thermal inkjet printing. Acoustic inkjet printers, on the other hand, use piezoelectric or acoustic actuators to eject more uniformly sized droplets and avoid exposing cells to thermal stress. Nonetheless, the high pressure, shear stress, and vibration frequency experienced by the cells during ejection pose significant drawbacks to cell viability and functionality (Cui et al., 2012; Cui et al., 2010). Compared to 3D bioplotting, the cell concentration within the fabricated scaffolds using thermal inkjet printers is smaller $\left(<10^{6}\right.$ cells $/ \mathrm{mL}$ ), as high cell concentration can clog the nozzle and reduce the shear forces needed for droplet formation (Xu et al., 2005). This is not necessarily disadvantageous, as high cell concentrations used in microextrusion bioprinting can reduce cell viability and functionality following printing (Ozbolat and Hospodiuk, 2016).

Material jetting is also used for bioceramic fabrication by mixing the ceramic powder into a liquid solvent and depositing the mixture using an inkjet printer. The 3D printed part should be dried and sintered to form a solid ceramic. This technique has been used for bone tissue engineering scaffolds using different bioceramic inks (Zhang et al., 2018).

Inkjet Printing

(a) Droplet-based Printing (DBP)

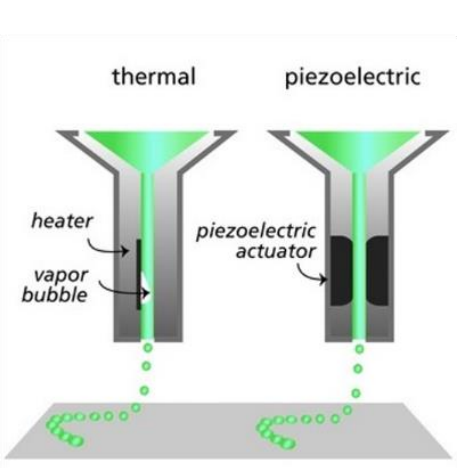

(b) Binder Jetting

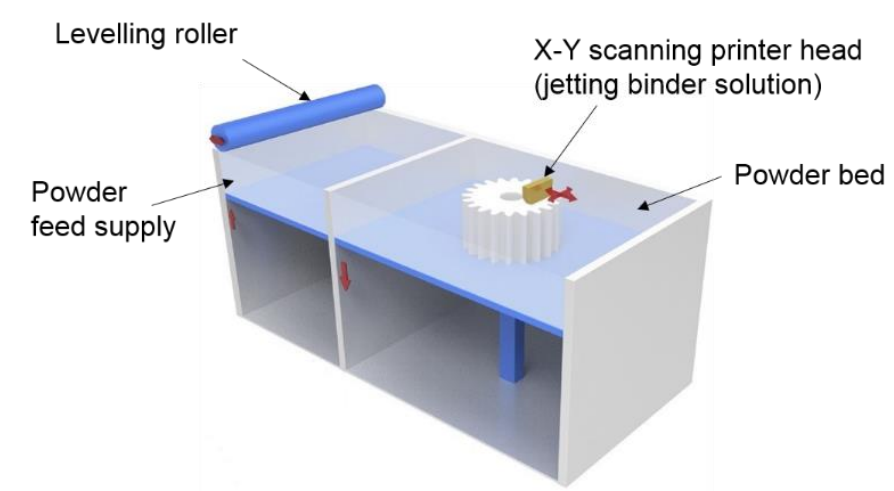

Fig. 4. Schematic of inkjet printing (a) Droplet-Based Printing (DBP) or material jetting, (b) Binder Jetting or Powder Binder Printer (PBP). Figures adapted with permission from (Malda et al., 2013), John Wiley \& Sons and (Chen et al., 2018), Elsevier respectively. 


\section{Powder Binder Printers (PBP)}

Binder jetting 3D printers, also known as powder binder printers (PBPs), eject droplets of binder solution onto a layer of powdered material, densely packed on the printer bed, to bind the powder. After printing each layer, the printer bed is lowered, a new layer of powder is rolled, and the process is repeated to build the 3D structure (Fig. 4.b). This platform is often utilised to print non-biological materials, although biological agents and cells can potentially be deposited using this technique as the system functions at room temperature (Chia and $\mathrm{Wu}$, 2015). Water is often used as a binder for tissue scaffold fabrication in PBP to avoid the need for toxic solvents (Lam et al., 2002). For instance, natural polymers (e.g. gelatin) using water solution as a binder have been printed using PBP (Katsumura et al., 2019). Synthetic polymers using organic solvents as binders have also been manufactured (Stansbury and Idacavage, 2016).

By jetting a ceramic binder on a ceramic powder packed on the printer bed, bioceramics can be produced. After printing, the object is sintered for removal of the binder and/or consolidation (Butscher et al., 2011). This technique has been widely used for bioceramic scaffold fabrications composed of HA (Seitz et al., 2005) and $\beta$-tricalcium phosphates ( $\beta$ TCPs) (Ke and Bose, 2018). In addition, binder jetting can be used for AM of metal and alloy parts from metallic powder. It has been used for AM of metal partial denture framework (Mostafaei et al., 2018) and fabrication of bone scaffolds using biodegradable $\mathrm{Fe}-\mathrm{Mn}-\mathrm{Ca} / \mathrm{Mg}$ alloys (Hong et al., 2016).

\subsection{Laser Assisted Bioprinting}

Laser assisted bioprinting (LAP) is a non-contact and nozzle-free material deposition system based on laser-induced forward transfer. It uses a laser-induced optical force to transfer droplets of biological material (e.g. cell encapsulated scaffolds) to a target substrate (see Fig. 5). By moving the substrate relative to the laser beam, the tissue is fabricated layer-by-layer (Odde and Renn, 1999). The biological material for printing is located on a thin film of metal coated on a transparent support, also known as ribbon. When the laser beam targets the ribbon, the metal film is locally vaporized and a jet of biological droplets is generated. These droplets are then deposited onto the target substrate (Guillotin et al., 2010).

The laser can target individual cells, transferring and depositing them to a desired location on the substrate. It has been shown that the cells remain viable and functional following LAP (Hopp et al., 2005; Odde and Renn, 1999). LAP resolution is dependent on several factors, including the laser energy density, viscosity, and thickness of the biological material coated on the ribbon (Guillotin et al., 2010). Although a very high printing resolution $(100 \mathrm{~nm}-10 \mu \mathrm{m})$ can be achieved using this technology, it has limited application for CT engineering compared to other bioprinting methods. Preparation of the ribbon is a relatively 
long process and consequently the printing process is slow (Gao et al., 2018; Murphy and Atala, 2014b; Odde and Renn, 1999).

\section{Laser Assisted Bioprinting}

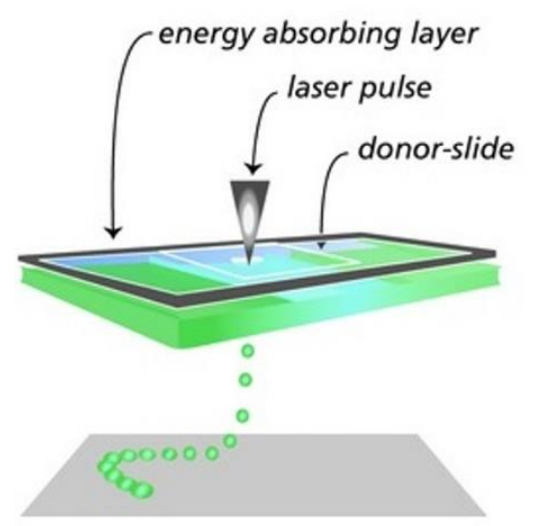

Fig. 5. Laser Assisted Bioprinting. Figures adapted from (Malda et al., 2013) with permission from John Wiley \& Sons 
Table 1 Compatible platforms for connective tissue (CT) engineering

\begin{tabular}{|c|c|c|c|c|c|}
\hline & $\begin{array}{l}\text { 3D Printing } \\
\text { Platform }\end{array}$ & Biomaterial Type & $\begin{array}{l}\text { Printing } \\
\text { Resolution }\end{array}$ & Benefits & Drawbacks \\
\hline \multirow{2}{*}{ 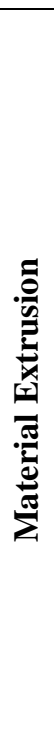 } & $\begin{array}{l}\text { Fused } \\
\text { Deposition } \\
\text { Modelling } \\
(\text { FDM })\end{array}$ & $\begin{array}{ll}\text { - } & \text { Thermoplastic } \\
\text { polymers } \\
\text { - } \\
\text { Polymer- } \\
\text { ceramic } \\
\text { composites } \\
\text { - Fibre-reinforced } \\
\text { polymers } \\
\text { - Bioceramics } \\
\end{array}$ & $\begin{array}{l}50-200 \mu \mathrm{m} \\
(\text { Ngo et al., 2018) }\end{array}$ & $\begin{array}{l}\text { - Low cost } \\
\text { - High speed }\end{array}$ & $\begin{array}{l}\text { - Low strength } \\
\text { - Limited materials } \\
\text { (biocompatible } \\
\text { thermoplastic) }\end{array}$ \\
\hline & $\begin{array}{l}\text { Direct Ink } \\
\text { Writing (DIW) }\end{array}$ & $\begin{array}{ll}\text { - } & \text { Synthetic and } \\
\text { natural } \\
\text { hydrogels } \\
\text { - Bioinks } \\
\text { - Bioceramics }\end{array}$ & $\begin{array}{l}5 \mu \mathrm{m}-1 \mathrm{~mm} \\
\text { (Murphy and Atala, } \\
2014 \mathrm{~b} \text { ) }\end{array}$ & $\begin{array}{l}\text { - Bioprinting } \\
\text { capability } \\
\text { - Capable of } \\
\text { printing high cell } \\
\text { concentrations } \\
\text { - Capable of } \\
\text { processing } \\
\text { relatively high } \\
\text { viscosity bioinks } \\
\text { - High resolution }\end{array}$ & $\begin{array}{l}\text { - Limited materials } \\
\text { (certain range of } \\
\text { viscosity) } \\
\text { - Low cell viability due } \\
\text { to cell distortion (for } \\
\text { bioinks) } \\
\text { - High resolution comes } \\
\text { with the cost of cell } \\
\text { distortion } \\
\text { - Relatively slow }\end{array}$ \\
\hline \multirow{2}{*}{ 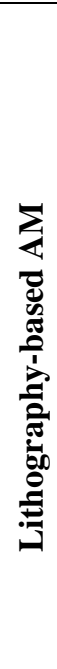 } & $\begin{array}{l}\text { Stereolithogra } \\
\text { phy (SLA) }\end{array}$ & $\begin{array}{l}\text { Photo- } \\
\text { crosslinkable } \\
\text { resin and } \\
\text { bioinks }\end{array}$ & $\begin{array}{l}10 \mu \mathrm{m} \\
\text { (Ngo et al., 2018) }\end{array}$ & $\begin{array}{l}\text { - High resolution } \\
\text { - Bioprinting } \\
\text { capability } \\
\text { - High cell } \\
\text { viability }\end{array}$ & $\begin{array}{l}\text { - Limited materials } \\
\text { (biocompatible and } \\
\text { photo-crosslinkable) } \\
\text { - High cell density } \\
\text { affects bioinks } \\
\text { crosslinking } \\
\text { - Expensive } \\
\text { - Slow }\end{array}$ \\
\hline & $\begin{array}{l}\text { Digital Light } \\
\text { Processing } \\
(\text { DLP) }\end{array}$ & $\begin{array}{l}\text { Photo- } \\
\text { crosslinkable } \\
\text { resin and } \\
\text { bioinks }\end{array}$ & $\begin{array}{l}25-50 \mu \mathrm{m} \\
\text { (Lim et al., 2018) }\end{array}$ & $\begin{array}{l}\text { - Relatively high } \\
\text { resolution } \\
\text { - High speed } \\
\text { - Bioprinting } \\
\text { capability } \\
\text { - High cell } \\
\text { viability }\end{array}$ & $\begin{array}{l}\text { - Limited materials } \\
\text { (biocompatible and } \\
\text { photo-crosslinkable) } \\
\text { - High cell density } \\
\text { affects crosslinking of } \\
\text { bioink }\end{array}$ \\
\hline \multirow{2}{*}{ 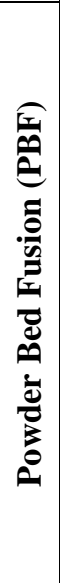 } & $\begin{array}{l}\text { Selective } \\
\text { Laser } \\
\text { Sintering } \\
(\text { SLS) }\end{array}$ & $\begin{array}{ll}\text { - } & \text { Metals and } \\
& \text { alloys } \\
\text { - } & \text { Polymers } \\
\text { - } & \text { Polymer- } \\
\text { ceramic } \\
\text { composites } \\
\text { - } \text { Bioceramics }\end{array}$ & $\begin{array}{l}80-250 \mu \mathrm{m} \\
(\text { Ngo et al., 2018) }\end{array}$ & $\begin{array}{l}\text { - Controllable } \\
\text { porosity } \\
\text { - High speed } \\
\text { - Good mechanical } \\
\text { properties }\end{array}$ & $\begin{array}{l}\text { - Expensive } \\
\text { - Poor surface quality } \\
\text { - Post-processing } \\
\text { needed }\end{array}$ \\
\hline & $\begin{array}{l}\text { Selective } \\
\text { Laser Melting } \\
(\mathrm{SLM})\end{array}$ & $\begin{array}{l}\text { - Metals and } \\
\text { alloys }\end{array}$ & $\begin{array}{l}80-250 \mu \mathrm{m} \\
\text { (Ngo et al., 2018) }\end{array}$ & $\begin{array}{l}\text { - No post- } \\
\text { processing } \\
\text { - High speed } \\
\text { - Dense printing } \\
\text { - superior } \\
\text { mechanical } \\
\text { properties }\end{array}$ & $\begin{array}{l}\text { - Very expensive } \\
\text { - Poor surface quality }\end{array}$ \\
\hline
\end{tabular}




\begin{tabular}{|c|c|c|c|c|c|}
\hline \multirow{3}{*}{ 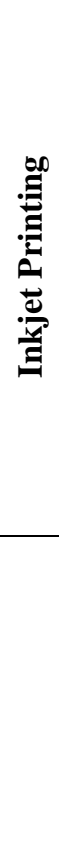 } & $\begin{array}{l}\text { Droplet-Based } \\
\text { Printing (DBP) }\end{array}$ & $\begin{array}{ll}\text { - } & \text { Synthetic and } \\
\text { natural } \\
\text { hydrogels } \\
\text { - } & \text { Bioinks } \\
\text { - } & \text { Bioceramics }\end{array}$ & $\begin{array}{l}50 \mu \mathrm{m} \\
\text { (Murphy and Atala, } \\
2014 \mathrm{~b} \text { ) }\end{array}$ & $\begin{array}{l}\text { - Bioprinting } \\
\text { capability } \\
\text { - Quick preparation } \\
\text { and printing } \\
\text { - Low cost }\end{array}$ & $\begin{array}{l}\text { - Limited materials (low } \\
\text { viscosity and should } \\
\text { form droplets) } \\
\text { - Low cell density } \\
\text { - Nozzle clogging } \\
\text { - Weak mechanical } \\
\text { strength }\end{array}$ \\
\hline & $\begin{array}{l}\text { Powder Binder } \\
\text { Printers } \\
\text { (PBPs) }\end{array}$ & $\begin{array}{ll}\text { - } & \text { Synthetic and } \\
& \text { natural } \\
& \text { hydrogels } \\
\text { - } & \text { Bioceramics } \\
\text { - } & \text { Metal and alloys }\end{array}$ & $\begin{array}{l}100-300 \mu \mathrm{m} \text { (Chia } \\
\text { and } \mathrm{Wu}, 2015)\end{array}$ & $\begin{array}{l}\text { - Quick preparation } \\
\text { and printing } \\
\text { - Low cost }\end{array}$ & $\begin{array}{l}\text { - Low resolution } \\
\text { - Low strength } \\
\text { - Post-processing } \\
\text { needed }\end{array}$ \\
\hline & $\begin{array}{l}\text { Laser Assisted } \\
\text { Bioprinting } \\
\text { (LAP) }\end{array}$ & $\begin{array}{ll}\text { - } & \text { Synthetic and } \\
\text { natural } \\
\text { hydrogels } \\
\text { - } & \text { Bioinks }\end{array}$ & $\begin{array}{l}5 \mu \mathrm{m} \\
\text { (Murphy and Atala, } \\
2014 \mathrm{~b} \text { ) }\end{array}$ & $\begin{array}{l}\text { - Nozzle-free } \\
\text { printing } \\
\text { - Capable of } \\
\text { printing high cell } \\
\text { concentrations } \\
\text { - Capable of } \\
\text { processing high } \\
\text { viscosity bioinks }\end{array}$ & $\begin{array}{l}\text { - Time consuming } \\
\text { preparation } \\
\text { - Expensive }\end{array}$ \\
\hline
\end{tabular}

\section{3) Mechanical Characterisation of Connective Tissues3.1 An Outline of the Mechanics of Soft Connective Tissues}

The mechanical behaviour of soft CT is determined by the composition of its ECM. Briefly, proteoglycans contain a protein core and glycosaminoglycans (GAGs) side chains. As GAGs are polyanionic, they attract water via the Donnan effect (Hukins et al., 1999). The result is formation of a highly hydrated gel. This hydrated gel, or ground substance, is reinforced by collagen fibrils, which provide the main resistance to deformation within CTs. Thus, soft CTs can be categorised as fibre-reinforced composite materials, where collagen provides reinforcement to the hydrated gel. In arterial walls, elastin is also a key constituent in determining its elastic behaviour (Wang et al., 2018), in particular its return to shape rather than stiffness.

Collagen fibrils have a crimped structure when unloaded. Under initial loading, soft CTs exhibit greater extensibility as the crimp is straightened (Fratzl et al., 1998). Once straightened, loading is then resisted by extended collagen fibrils, which leads to increased tissue stiffness (i.e. reduced extensibility per load). The result is a characteristic ' $J$ '-shaped stress-strain (or force-displacement) relationship. Strain energy potential material models such as Ogden or Yeoh have, therefore, been used to characterise the mechanical behaviour of soft CTs (Martins et al., 2006; Misra et al., 2010). Indeed, constitutive models such as the Holzapfel-Gasser-Ogden model (Holzapfel et al., 2000) incorporate the relative contributions of fibres and matrix, including fibre orientation, in numerical models of soft CTs (Lavecchia et al., 2018).

Fibre orientation is important because collagen provides reinforcement to loading primarily along its longitudinal axis. Therefore, the method by which this resistance to deformation is achieved depends on the structuring of the tissue itself and the preferred orientation of collagen fibres (Hukins and Aspden, 1985). For example, an intervertebral disc consists of a central gel (nucleus pulposus) surrounded by layers (lamellae) containing collagen oriented at $\pm 30^{\circ}$. Thus, under compression, the fluid gel places collagen under tension (White, 
1990). Articular cartilage is differently structured and is primarily exposed to compression, and also requires collagen fibres to be placed under tension so as to provide reinforcement to deformation during compressive loading (Hukins et al., 1984; Zhang et al., 2015). Collagen is aligned parallel to the surface layer at the superficial region of cartilage, perpendicular to the surface layer in its mid- and deep-zones, and with a transition layer in between (Athanasiou et al., 2013). It is a swelling pressure which places the ECM and its collagen fibres under tension (Aspden and Hukins, 1990; Hukins et al., 1984).

The structuring of collagen within soft CTs can be straightforward in places where the tissue is primarily exposed to tension. For example, chordae tendineae have collagen primarily aligned with their longitudinal axis (Millington-Sanders et al., 1998). This is also often the case for tendons and ligaments. The crimp period has been hypothesised as determining the transition from highly extensible to inextensible within such CTs, with a shorter crimp period being associated with greater extensibility (Liao and Vesely, 2003). There is also evidence that triple helical tropocollagen molecules, which compose collagen, follow entropic elasticity at low strains but energetic elasticity at larger strains (Buehler and Wong, 2007). Therefore, there is a transition to a more ordered state initially, which relates to the large extension at low strains of soft tissues. Subsequently, at a more ordered state, these tissues undergo low extension (Misof et al., 1997; Puxkandl et al., 2002).

The material properties of soft CTs are dependent on their rate of loading; they are viscoelastic (Burton et al., 2017; Espino et al., 2012; Sadeghi et al., 2015a). A viscoelastic material can be characterised in terms of its ability to store and dissipate energy, referred to as the storage and loss moduli respectively. This time-dependency can be used to describe phenomena such as creep, stress relaxation, and hysteresis. These characteristics correspond to continued extension of a material at constant load (creep), the reduction in stress within a material held at constant strain (stress relaxation), and the dissipation of energy during a loading-unloading cycle (hysteresis). Under dynamic loading, the stress and strain (or load and displacement) will be out of phase by a phase lag $(\delta)$. Dissipation of energy can be associated with viscous flow through a material, which for soft CTs might be associated with its fluid content; in fact, many soft tissues have poroelastic properties (Ghimire et al., 2018; Han et al., 2011; Miramini et al., 2016b; Tavakoli Nia et al., 2011; Zhang et al., 2008). However, while tissues such as articular cartilage contain around $70 \%$ water content (Armstrong and Mow, 1982; Venn, 1978; Venn and Maroudas, 1977), water bound to GAGs is not necessarily freely available to flow. This might be analogous to water in hydrogels which can be bound to polymers or trapped within voids (Meakin et al., 2003). Indeed, the stress transfer between fibre and ground substance (Goh et al., 1999; Goh et al., 2004; Goh et al., 2003) may be central to the viscoelastic behaviour rather than individual constituents independently, or exclusively, contributing to viscous and elastic behaviour (Pearson and Espino, 2013).

\subsection{Material Properties of Arteries (Coronary, Femoral and the Aorta), Articular Cartilage, and Bone}

Indicative material properties and failure stresses are provided for arteries (coronary, femoral, and aorta), articular cartilage, and bone in Table 2 . The values provided are intended as an indicative range for which AM replacement materials may target in the first instance. However, some caveats apply, some of which are outlined below, others noted in Table 2.

A major difference between bone and soft CTs is that while collagen fibres are present to provide reinforcement under tensile loading, the ECM of bone is mineralised by HA (although impure, and poorly crystalline) (Hukins et al., 1999). The result is that it is able to support compressive loads. There is a link between bone mineral density (BMD) and its 
mechanical properties (Carter and Hayes, 1977; Novitskaya et al., 2011). This may be explained by bone remodelling and Wolf's Law (Bonfield and Clarke, 1973; Helgason et al., 2008; Novitskaya et al., 2011; Schaffler and Burr, 1988; Wachter et al., 2001). There is interest in clinical applications because of the possibility to measure BMD from clinical scans and map the local elastic modulus in 3D space (Grassi et al., 2014; Grassi et al., 2012). Potential applications to numerical models include prediction of failure propagation (Juszczyk et al., 2010) as well as prediction of cell differentiation and ossification during bone fracture healing (Ganadhiepan et al., 2019b; Miramini and Yang, 2019; Miramini et al., 2016a; Zhang et al., 2017b). Bone can be categorised as cortical and cancellous (also referred to as trabecular or spongy) (Fig. 6). Cortical bone is more densely packed and, therefore, stiffer and stronger than cancellous bone. Cortical bone lies furthest away from the neutral axis of bones and is exposed to higher stresses during loading. For both cortical and cancellous bone, there are a range of experimental parameters which influence measurements of mechanical properties, including specimen age and testing protocols (e.g. hydration, rate of testing, longitudinal or transverse test samples, etc.) (Lucas et al., 1999; Novitskaya et al., 2011). Moreover, lower elastic modulus and failure stresses are observed under tension than under compression (Keaveny and Buckley, 2006; Kopperdahl and Keaveny, 1998).

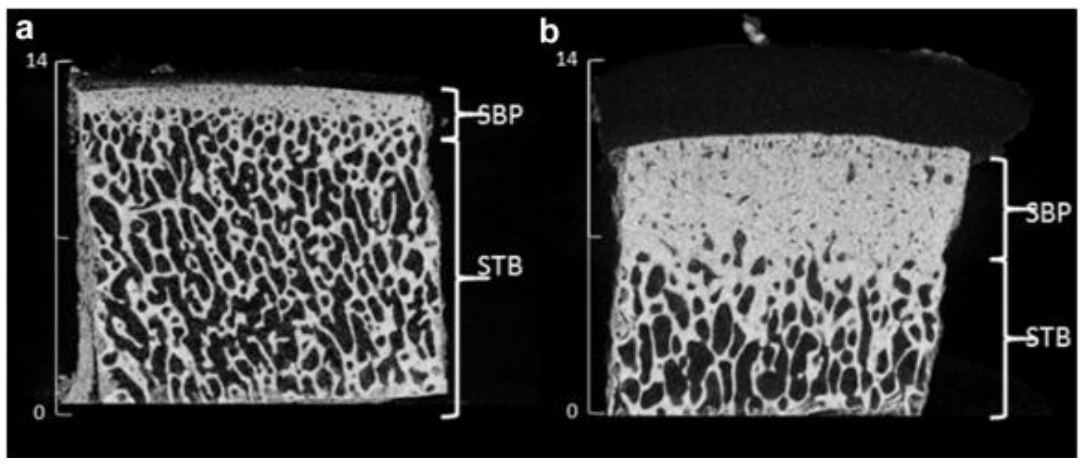

Fig. 6. Bovine knee joint subchondral bone, including a subchondral plate (SBP) and subchondral trabecular bone (STP). (a) Sample from a meniscus covered region. (b) Sample from a non-meniscus covered region of the tibial plateau. Note: Figure reproduced from (Fell et al., 2019) which is distributed under the terms of the Creative Commons Attribution 4.0 International License (http://creativecommons.org/licenses/by/4.0/)

The instantaneous elastic modulus for articular cartilage will vary both per joint and per location within the joint (Shepherd and Seedhom, 1999). This may be an adaptive response to the stresses to which the tissue is exposed (Swann and Seedhom, 1993). Additionally, high rates of testing will result in greater values for the calculated elastic moduli (Burgin and Aspden, 2008; Lawless et al., 2017). Methods which calculate elastic moduli following equilibrium under static loading predict greater compliance (Athanasiou et al., 1991; Taylor et al., 2012). Regarding failure, an injurious stress might still classify as being within a physiological range. For instance, a stress of 4-6 MPa may be induced on the patellar surface of femur when walking up and down stairs or ramps (Seedholm et al., 1979). Vigorous activity may induce stresses in the range of 12-18 MPa (Hodge et al., 1989; Mathews and Decker, 1977). Failure of soft CTs may involve propagation of a crack (Fig. 7) along or through the tissue (Sadeghi et al., 2017; Sadeghi et al., 2018; Sadeghi et al., 2015b). This means that an 
objective criterion for failure is more difficult to define as compared to a hard CT such as bone, as functionality may continue following failure.

Pressure vessels, such as arteries, contain collagen orientated so as to resist circumferential (i.e. aligned with the circumference of the artery) and longitudinal (i.e. aligned along the length of the artery) loading (Fig. 8). Arteries are typically comprised of three layers: the tunica intima, the tunica media, and the tunica adventitia (or tunica externa). The intima, in contact with the blood, is comprised of an endothelial monolayer supported by a subendothelial layer of loose CT. By contrast, the tunica media contains smooth muscle cells, and the tunica adventitia is primarily constituted of collagen and elastin (Lowe and Anderson, 1997). Coronary and femoral arteries have a similar collagen content, with coronary arteries containing the highest ratio of collagen to elastin (Fischer and Llaurado, 1966). In the coronary adventitia, longitudinal stiffness is a direct result of initial fibre alignment, with collagen fibres uniformly stretching in the loading direction (Chen et al., 2013; Karimi et al., 2016). Material properties are dependent on the orientation of the loading, with characterisation focused on circumferential and longitudinal properties (Yang et al., 2009).

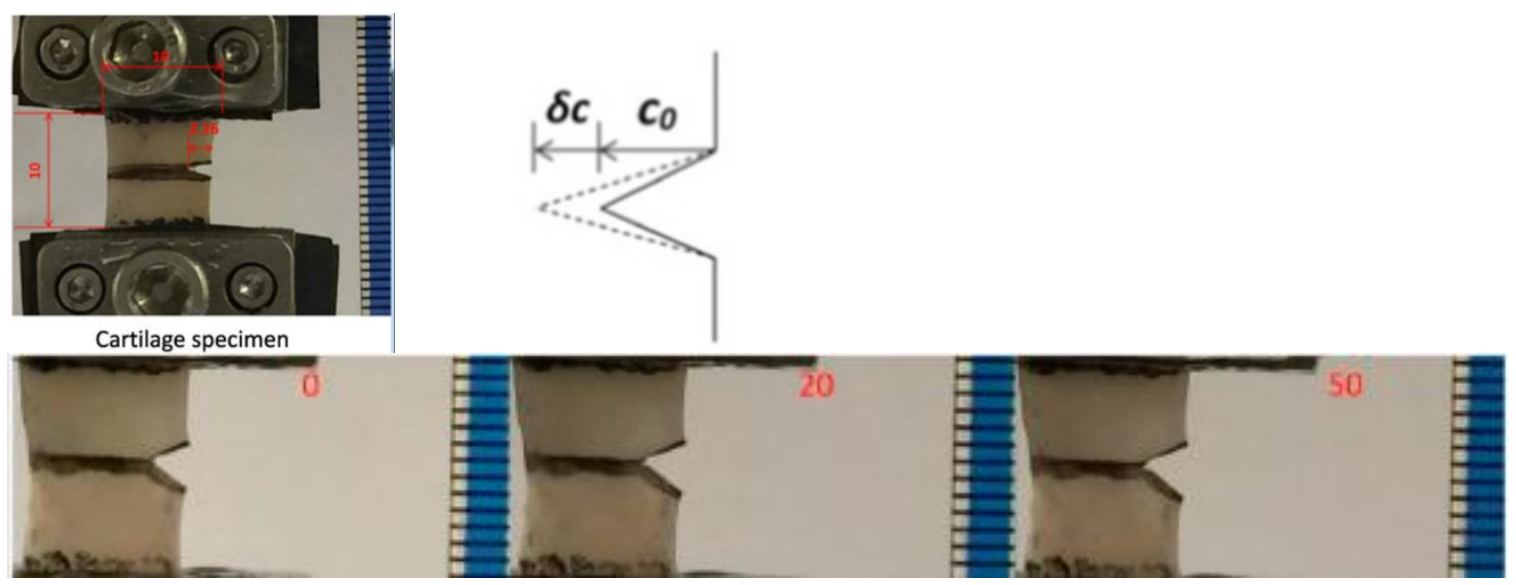

Fig. 7. Crack propagation through articular cartilage, with an initial notch (c0). The numbers 0,20 and 50 refer to the number of cycles of loading. Note: This figure has been reproduced from (Sadeghi et al., 2018), which is distributed under the terms of the Creative Commons Attribution 4.0 International License (http://creativecommons.org/licenses/by/4.0/)

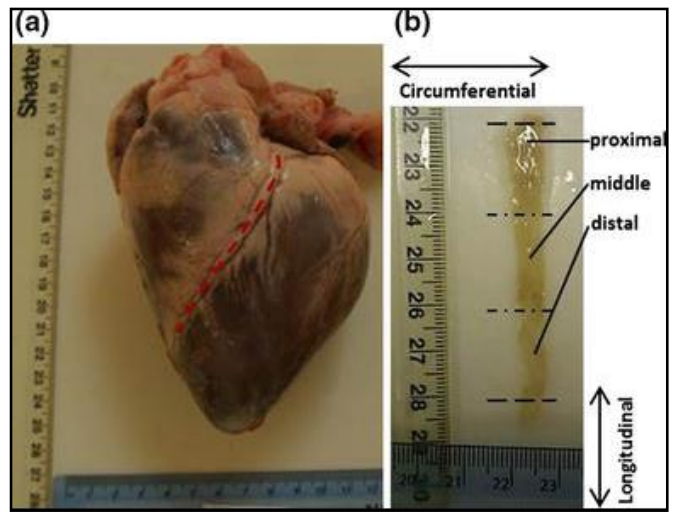

Fig. 8. Porcine heart. (a) The dashed line identifies the location of the left anterior descending coronary artery. (b) The coronary artery dissected with the endothelial surface exposed. Note: This figure has been reproduced from (Burton et al., 2017), which is distributed under the terms 
of the Creative Commons Attribution 4.0 International License (http://creativecommons.org/licenses/by/4.0/) 
Table 2 Indicative 'elastic' moduli and failure stresses for arteries, articular cartilage, and bone

\begin{tabular}{|c|c|c|c|}
\hline CT Type & Elastic Modulus (or equivalent) & Failure Stress & Notes \\
\hline Arteries & 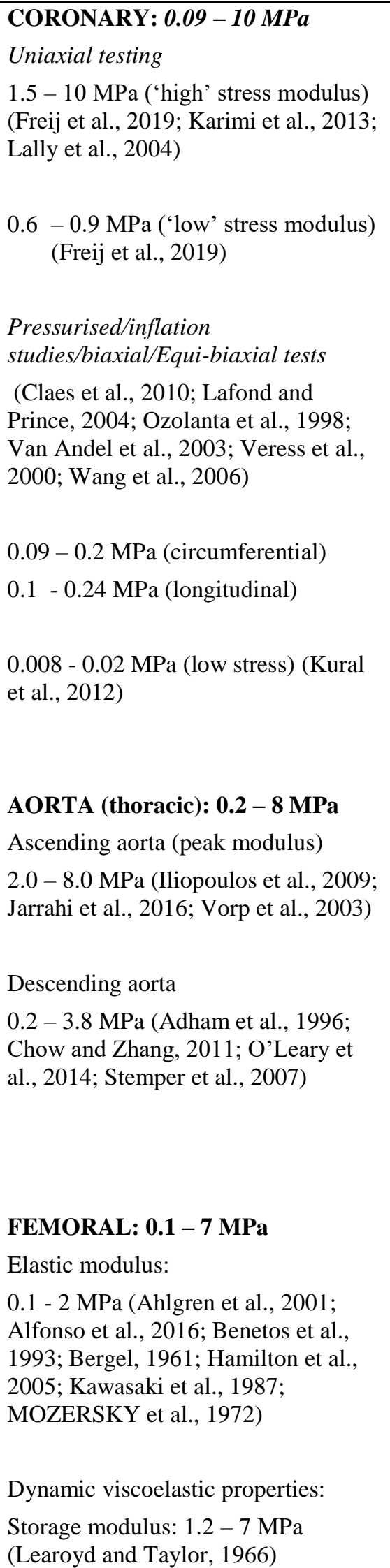 & $\begin{array}{l}\text { CORONARY: } \mathbf{0 . 4} \text { MPa } \\
\text { Tensile strength: 0.4 } \\
\text { MPa (Holzapfel et al., } \\
\text { 2005) } \\
\text { Intima } \\
\text { 0.39 MPa (Holzapfel et } \\
\text { al., 2005) } \\
\text { Media } \\
\text { 0.45 MPa (Holzapfel et } \\
\text { al., 2005) } \\
\text { Adventitia } \\
\text { 1.4 MPa (Holzapfel et } \\
\text { al., 2005) } \\
\text { FEMORAL: } \geq \mathbf{0 . 3} \text { MPa } \\
\text { (Schulze-Bauer et al., } \\
\text { 2002; Syedain et al., } \\
\text { 2011) } \\
\text { Descending aorta } \\
\text { 0.8 - 5.1 MPa (Adham et } \\
\text { al., 1996; Groenink et al., } \\
\text { 1999; Mohan and } \\
\text { Melvin, 1982, 1983; } \\
\text { Stemper et al., 2007) } \\
\text { 1.0-2.2 MPa (Iliopoulos } \\
\text { 2016; Vorp et al., 2003) } \\
\text { AORTA (thoracic): 0.8 } \\
\text {-5.1 MPa } \\
\text { Ascending aorta }\end{array}$ & $\begin{array}{l}\text { Failure stress does not necessarily mean full } \\
\text { 'fracture' and more subtle signs of damage } \\
\text { may be noticeable at below failure stress } \\
\text { (Burton and Espino, 2019) } \\
\text { Longitudinal and transverse samples, rate of } \\
\text { loading (Mohan and Melvin, 1982), animal } \\
\text { samples or human samples, age, and testing } \\
\text { using uniaxial or biaxial set-ups (O'Leary et } \\
\text { al., 2014) will lead to different elastic } \\
\text { moduli. Some of these points have been } \\
\text { highlighted for coronary arteries, along with } \\
\text { the difference between low and high stress } \\
\text { characterisation (but not for aorta and } \\
\text { femoral arteries, to avoid repetition) }\end{array}$ \\
\hline
\end{tabular}




\begin{tabular}{|c|c|c|c|}
\hline & $\begin{array}{l}\text { Loss modulus: } 0.14-1.6 \mathrm{MPa} \\
\text { (Learoyd and Taylor, 1966) }\end{array}$ & & \\
\hline $\begin{array}{l}\text { Articular } \\
\text { Cartilage }\end{array}$ & $\begin{array}{l}\text { RANGE: <1 - 170 MPa } \\
\text { Knee: } 6 \text { - 11.8 MPa (Shepherd and } \\
\text { Seedhom, 1999) } \\
\text { Hip : } 4.5 \text { - 10.2 MPa (Shepherd and } \\
\text { Seedhom, 1999) } \\
\text { Equilibrium \& aggregate moduli } \\
=<1 \mathrm{MPa} \text { (Athanasiou et al., 1991; } \\
\text { Taylor et al., 2012) } \\
\text { 'Dynamic' modulus } \leq 170 \mathrm{MPa} \\
\text { (Burgin and Aspden, 2008) } \\
\text { Dynamic viscoelastic properties: } \\
\text { Storage modulus = 20 MPa - } 114 \\
\text { MPa (Lawless et al., 2017) } \\
\text { Loss modulus = } 4-20 \mathrm{MPa} \text { (Lawless } \\
\text { et al., 2017) }\end{array}$ & $\begin{array}{l}\text { RANGE: 4-50 MPa } \\
>4 \mathrm{MPa} \text { (surface damage } \\
\text { under dynamic loading) } \\
\text { (Sadeghi et al., 2015b) } \\
\text { 8-10 MPa (under a static } \\
\text { load) (Fick and Espino, } \\
\text { 2011, 2012) } \\
\text { However pure traumatic } \\
\text { loading might be in the } \\
\text { range of: } \\
\text { 10-50 MPa } \\
\text { (Jeffrey and Aspden, } \\
\text { 2006; Milentijevic et al., } \\
\text { 2005; Milentijevic and } \\
\text { Torzilli, 2005); }\end{array}$ & $\begin{array}{l}\text { Mechanical properties of articular cartilage } \\
\text { are dependent on the joint which it lines, as } \\
\text { well as the location within the joint (likely } \\
\text { determined by prevalent stress) } \\
\text { Trauma or fissures of cartilage may alter its } \\
\text { mechanical behaviour } \\
\text { Some form of damage may occur within a } \\
\text { 'physiological range' of loading }\end{array}$ \\
\hline Bone & $\begin{array}{l}\text { CORTICAL: } \mathbf{1 0}-\mathbf{4 0} \mathbf{G P a} \\
\text { (Bonfield and Clarke, 1973; Carter } \\
\text { and Hayes, 1977; Novitskaya et al., } \\
\text { 2011) } \\
\text { CANCELLOUS: } \mathbf{0 . 4}-\mathbf{1 8 ~ G P a} \\
\text { (Gibson, 1985; Lucas et al., 1999; } \\
\text { Novitskaya et al., 2011) }\end{array}$ & $\begin{array}{l}\text { CORTICAL: } 125- \\
\text { 250 MPa } \\
\text { (Carter et al., 1981; } \\
\text { Öhman et al., 2011) } \\
\text { CANCELLOUS: } 0.3 \text { - } \\
\mathbf{3 0 ~} \mathbf{M P a} \\
\text { Femur = } 1-30 \mathrm{MPa} \\
\text { (Perilli et al., 2008) } \\
\text { Vertebrae = } 0.36-2.34 \\
\text { MPa (Nazarian et al., } \\
\text { 2006) }\end{array}$ & 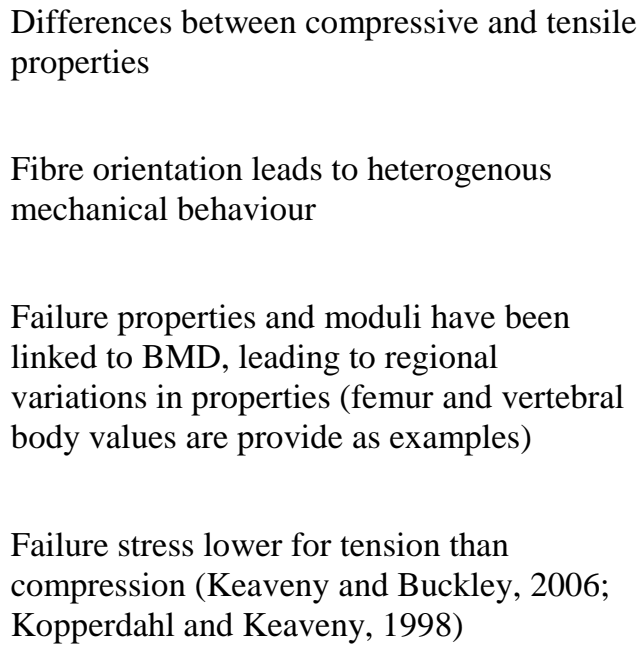 \\
\hline
\end{tabular}




\section{4) Biomaterials for AM of Connective Tissues}

A wide range of biocompatible, printable materials are available for use in CT engineering. Table 3 summarises additively manufacturable biomaterials suitable for CT engineering. Non-biodegradable biomaterials can be used for both long term and permanent tissue support, or as tissue replacements. Such materials are seen in orthopaedic implants, vascular stents, and dental crowns. They serve several functions pertinent to CT, including load-bearing, void-filling, and widening and reconstruction of the body's passageways. Biodegradable biomaterials, on the other hand, act as temporary scaffolds for promoting cell proliferation, migration, differentiation, and ultimately tissue regeneration. They can also assist drug delivery after implantation. This section summarises the critical properties of these biomaterials that significantly influence CT implant function and performance.

\subsection{Biocompatibility}

The biocompatibility of AM materials is pivotal for successful implantation. Biocompatibility is defined as "the ability to perform with an appropriate host response in a specific situation" (Williams, 1987). It should be noted that both biomaterial variability and host factors affect the biocompatibility of an implant (Williams, 1989). In addition, implant biocompatibility is not only affected by the intrinsic properties of the printing material, but also by fabrication process parameters (e.g. extrinsic properties such as porosity and surface characteristics) (De Maria et al., 2015). Ideally, a biomaterial should have biochemical and biophysical properties akin to the host tissue to avoid mechanical failure, undesired immune response, chronic inflammation, and allergic reaction. Furthermore, the biomaterial should promote cellular activities involved in CT function, as well as tissue integration and/or regeneration. As illustrated in Fig. 9, several interrelated components are involved in the biocompatibility characteristics of an implant, including biomaterial integration and degradation as well as structural and mechanical properties.

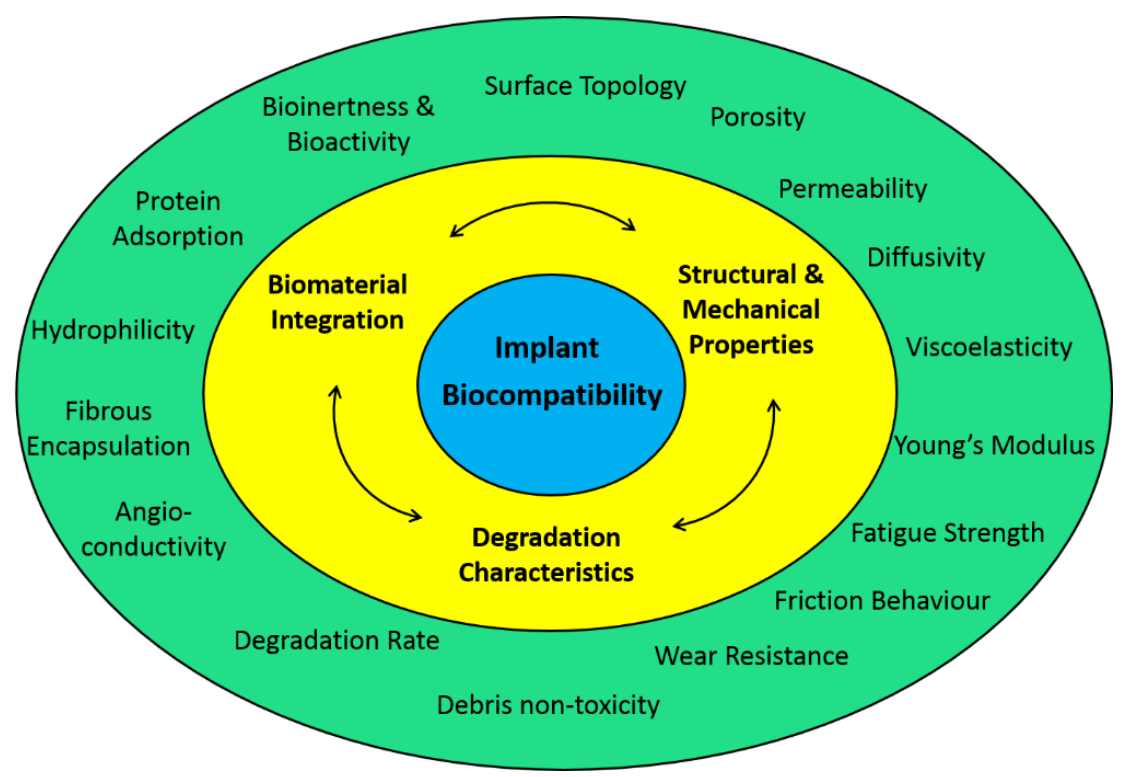

Fig. 9. Summary of the parameters affecting a CT implant biocompatibility 


\subsubsection{Biomaterial integration}

Integration of the implanted biomaterial into the surrounding host tissue, i.e. biointegration, is of critical importance for its long-term viability. Biointegration is highly influenced by host foreign-body reactions such as protein adsorption and inflammation/repair response. The implant surface chemistry, nano-topography and hydrophilicity can highly affect the protein adsorption process and consequently the implant biointegration. Therefore, material composition, implant design and the fabrication process play key roles in surface function for the protein adsorption process (Serra et al., 2013). Surface functionalisation of the implant can be performed physically or chemically. Physical functionalisation modifies the surface nanomorphology and topography physically with minimal changes to the surface chemistry, whereas chemical modification changes the chemistry of the implant surface by applying a surface coating or by oxidising, nitriding or carbiding the material (Bose et al., 2018).

In addition, the balance between inflammatory and repair processes of the host tissue following biomaterial implantation, significantly impacts implant biointegration. A highly bioinert material, such as pure titanium, alumina, or ultra-high molecular weight polyethylene, has minimal interaction with the host tissue. As such, the inflammation and repair response are minimally disrupted, and minimum fibrous encapsulation occurs if the implant is tightly fixed within the host tissue. Weakly bioinert materials or loosely confined implants experience more unfavourable biointegration as they elicit persistent inflammatory stimuli, resulting in implant encapsulation by a thicker fibrous capsule. On the other hand, bioactive materials such as $\beta$ TCP and bioactive glasses promote a balanced inflammation and repair response, yielding improved angiogenesis, tissue regeneration, bonding to the implant interface and biointegration.

In addition, the porosity of a biomaterial affects its biointegration. Porous biocompatible materials allow $\mathrm{CT}$ penetration via the pore network, thus encouraging implant integration. Furthermore, biodegradable porous implants degrade concomitantly with CT ingrowth until the implant is fully replaced by regenerated tissue. Fibrous encapsulation and biointegration of a biodegradable implant are highly influenced by its bioactivity. While naturally derived biodegradable scaffolds (e.g. collagen- and $\beta$-TCP based) integrate well, highly bioinert biodegradable materials such as PCL stimulate formation and continuous remodelling of the fibrous capsule around the implant (Narayan, 2018; Williams, 1989).

\subsubsection{Degradation characteristics}

The degradation characteristics of a material are determined by the complex biochemical and biophysical environment of the host CT. Tissues contain a variety of ions, organic species (e.g. proteins), and active cells at physiological temperature. Moreover, CT is subject to physical loading, deformation and fatigue stress, all of which provide a highly susceptible environment for material degradation. Unwanted degradation of an implant not only affects its structural and mechanical performance, but also results in release of material debris which can cause adverse body reactions and post-surgical complications. This debris is difficult to remove and often results in prolonged inflammation and repair response and further complications (Williams, 1989). For example, it has been shown that the wear debris of the materials used in orthopaedic implants (e.g. polyethylene, metal, and ceramic) trigger inflammation response and can potentially result in implant loosening and failure (Philbrick et al., 2018). 
Biodegradable biomaterials with controlled degradation, on the other hand, are used in regenerative medicine to provide a temporary support for cellular activities and CT regeneration. Their degradation rate, non-toxicity, and biocompatibility are the main factors affecting scaffold success. It is challenging to develop a biodegradable biomaterial that degrades at the same rate as the tissue regeneration. The degradation rate is often too fast or too slow to allow synchronised degradation and tissue regeneration (Zhang et al., 2014). Naturally derived polymers (e.g. collagen, chitosan, alginate, gelatine, keratin and silk) have superior biocompatibility and promote cellular activities, angiogenesis, and tissue regeneration. However, they possess inferior and inconsistent mechanical properties, limited control over degradation rate, and potential immunogenic response (Ige et al., 2012). Synthetic biodegradable polymers (e.g. PLA, polyglycolide (PGA), poly(lactic-co-glycolic acid) (PLGA), PCL, PPF) offer several advantages, including relative ability to tailor mechanical and degradation properties, high reproducibility, and availability. Nevertheless, they suffer from high bio-inertness and lower biocompatibility compared with natural polymers. Other biodegradable materials commonly used in bone tissue regeneration include biodegradable bioceramics such as $\beta$-TCP that offer high bioactivity and suitable mechanical properties and biodegradation rate, enhancing scaffold osteoconductivity (Martin and Bettencourt, 2018).

\subsection{Printability}

An ideal biomaterial for AM should allow accurate and precise printing with favourable spatiotemporal control, a material characteristic known as printability. Material printability is determined by the material's intrinsic properties and extrinsic printing parameters. For example, materials used in powder-based 3D printers such as PBPs require specific particle size and good sphericity alongside good flowability (Mazzoli, 2013). Inkjet printing platforms such as DBP need materials with specific viscosity and rapid crosslinking capabilities. Meanwhile, microextrusion techniques such as DIW require materials with shear thinning properties. In addition, within the scope of bioink printing, other printability requirements are necessitated to ensure high cell viability after printing. For example, thermal inket bioprinters need bioinks with low thermal conductivity to minimise cell temperature increase during the printing process. On the other hand, microextrusion bioprinters should avoid highly viscous bioinks with low shear thinning characteristics. Otherwise, high shear stress at the nozzle during extrusion can damage the cells (Butscher et al., 2011; Gopinathan and Noh, 2018; Murphy and Atala, 2014b). Fig. 10 shows the inter-related parameters affecting printability and cell viability of hydrogels and bioinks. 


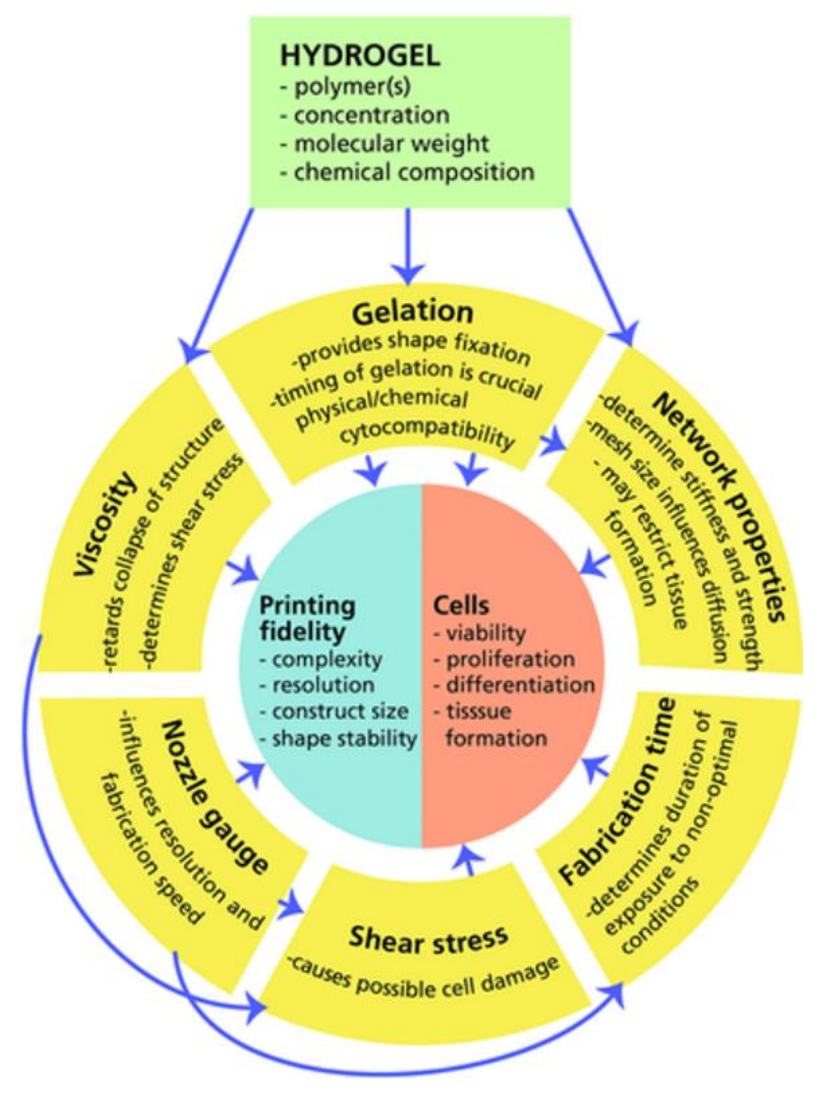

Fig. 10. Parameters affecting printability and cell viability of bioinks (i.e. cell encapsulated hydrogels). Image is reprinted from (Malda et al., 2013) with permission from John Wiley \& Sons. 
Table 3 Biomaterials for 3D printing of connective tissues. Asterisk indicates bioinks printing capability

\begin{tabular}{|c|c|c|c|c|c|c|c|}
\hline \multicolumn{2}{|c|}{ Biomaterial } & Platforms & Applications & Benefits & Drawbacks & 3D Printing Challenges & References \\
\hline \multirow{3}{*}{ 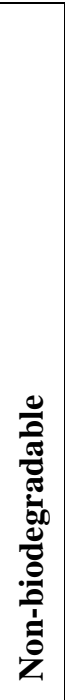 } & Metals & $\begin{array}{l}\text { SLS, } \\
\text { SLM, } \\
\text { DED }\end{array}$ & $\begin{array}{l}\text { - Bone fracture fixation } \\
\text { - Joint replacement } \\
\text { - Dental implants } \\
\text { - Vascular stent }\end{array}$ & $\begin{array}{l}\text { - High strength and } \\
\text { reliability } \\
\text { - Relative ductility } \\
\text { - Easy to 3D print }\end{array}$ & $\begin{array}{l}\text { - Stress-shielding } \\
\text { - Weak osseointegration } \\
\text { - Release of wear debris } \\
\text { - Hypersensitivity reactions }\end{array}$ & $\begin{array}{l}\text { - Finishing } \\
\text { - Limited Materials } \\
\text { - Cost } \\
\text { - Scalability } \\
\text { - Wear properties }\end{array}$ & $\begin{array}{l}\text { (Gokuldoss et al., } \\
\text { 2017; Lee et al., 2017; } \\
\text { Mazzoli, 2013) }\end{array}$ \\
\hline & Bioceramics & $\begin{array}{l}\text { FDM, } \\
\text { DIW, } \\
\text { SLA, } \\
\text { DLP, } \\
\text { SLS, } \\
\text { SLM }\end{array}$ & $\begin{array}{l}\text { - Coating of orthopaedic } \\
\text { and dental implants } \\
\text { - Joint replacement }\end{array}$ & $\begin{array}{l}\text { - Wear resistant } \\
\text { - Bioinert } \\
\text { - High compressive } \\
\text { strength } \\
\text { - Osteoconductive } \\
\text { - Low friction }\end{array}$ & $\begin{array}{l}\text { - Brittle } \\
\text { - Low tensile strength } \\
\text { - Low fatigue strength } \\
\text { - Complex fabrication } \\
\text { technique }\end{array}$ & $\begin{array}{l}\text { - Post processing is } \\
\text { normally required }\end{array}$ & $\begin{array}{l}\text { (Chen et al., 2018; } \\
\text { Guvendiren et al., } \\
\text { 2016) }\end{array}$ \\
\hline & Polymers & $\begin{array}{l}\text { FDM, } \\
\text { SLA, } \\
\text { DLP, } \\
\text { SLS }\end{array}$ & $\begin{array}{l}\text { - Soft CT scaffolds } \\
\text { (cartilage replacement and } \\
\text { vascular grafts) }\end{array}$ & $\begin{array}{l}\text { - Flexible } \\
\text { - Easy fabrication } \\
\text { - Durable }\end{array}$ & $\begin{array}{l}\text { - Can deform or degrade with } \\
\text { time } \\
\text { - Weak cell adhesion }\end{array}$ & $\begin{array}{l}\text { - Limited materials } \\
\text { - Limited manufacturing } \\
\text { methods }\end{array}$ & $\begin{array}{l}\text { (Melchels et al., 2012; } \\
\text { Stansbury and } \\
\text { Idacavage, 2016) }\end{array}$ \\
\hline \multirow[b]{2}{*}{ 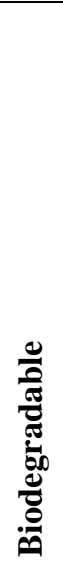 } & $\begin{array}{l}\text { Synthetic } \\
\text { polymers }\end{array}$ & $\begin{array}{l}\text { FDM, } \\
\text { DIW**, } \\
\text { SLA*, } \\
\text { DLP*, } \\
\text { SLS, } \\
\text { DBP*, } \\
\text { PBP, } \\
\text { LAP* }\end{array}$ & \multirow[t]{2}{*}{$\begin{array}{l}\text { - Soft CT scaffolds } \\
\text { (cartilage replacement and } \\
\text { vascular grafts) } \\
\text { - Hard CT scaffolds (bone) } \\
\text { stabilised by fixation }\end{array}$} & $\begin{array}{l}\text { - Flexible } \\
\text { - Easy processing } \\
\text { - Versatile } \\
\text { - High control over } \\
\text { degradation }\end{array}$ & $\begin{array}{l}\text { - Low stiffness } \\
\text { - Limited biocompatibility and } \\
\text { cell affinity }\end{array}$ & - Limited materials & $\begin{array}{l}\text { (Asghari et al., 2017; } \\
\text { Guvendiren et al., 2016; } \\
\text { Lei and Wang, 2016) }\end{array}$ \\
\hline & $\begin{array}{l}\text { Natural } \\
\text { polymers }\end{array}$ & $\begin{array}{l}\text { DIW**, }^{*} \\
\text { DLP* }^{*} \\
\text { MET, } \\
\text { DBP*, } \\
\text { PBP, } \\
\text { LAP* }^{*}\end{array}$ & & $\begin{array}{l}\text { - High cell affinity } \\
\text { - Osteoinductive } \\
\text { - Osteoconductive } \\
\text { - Promotes angiogenesis } \\
\text { - Safe degradation } \\
\text { byproducts }\end{array}$ & $\begin{array}{l}\text { - Low stiffness } \\
\text { - Batch-to-batch variability } \\
\text { - Limited printability } \\
\text { - Risk of immune response }\end{array}$ & $\begin{array}{l}\text { - Limited material } \\
\text { processability and } \\
\text { printability }\end{array}$ & $\begin{array}{l}\text { (Liu et al., 2018; Yang } \\
\text { et al., 2018) }\end{array}$ \\
\hline
\end{tabular}




\begin{tabular}{|c|c|c|c|c|c|c|}
\hline Bioceramics & $\begin{array}{l}\text { FDM, } \\
\text { DIW, } \\
\text { SLA, } \\
\text { DLP, } \\
\text { SLS, } \\
\text { PBP }\end{array}$ & - Hard CT scaffolds (bone) & $\begin{array}{l}\text { - High stiffness } \\
\text { - Osteoconductive }\end{array}$ & - Limited osteoinductivity & $\begin{array}{l}\text { - Post processing is } \\
\text { normally required }\end{array}$ & $\begin{array}{l}\text { (Ashammakhi et al., } \\
\text { 2019; Chen et al., } \\
\text { 2018; Guvendiren et } \\
\text { al., 2016; Wen et al., } \\
\text { 2017) }\end{array}$ \\
\hline $\begin{array}{l}\text { Hybrid/ } \\
\text { Composite } \\
\text { Materials }\end{array}$ & $\begin{array}{l}\text { FDP, } \\
\text { DIW, } \\
\text { SLA, } \\
\text { DLP, } \\
\text { SLS, } \\
\text { PBP }\end{array}$ & $\begin{array}{l}\text { - Bioceramic-polymer } \\
\text { composite for hard CT } \\
\text { (bone) } \\
\text { - Composite polymers for } \\
\text { arterial tissue }\end{array}$ & $\begin{array}{ll}- & \text { Improved mechanical } \\
\text { properties } \\
\text { - } & \text { Improved } \\
\text { biocompatibility }\end{array}$ & - Limited materials & - Long preparation time & $\begin{array}{l}\text { (Ashammakhi et al., } \\
\text { 2019; Guvendiren et } \\
\text { al., 2016) }\end{array}$ \\
\hline
\end{tabular}




\section{5) Structural and Mechanical Characterisation of AM Materials for Connective Tissue Replacement}

Replication of the mechanical properties of host CT is of critical importance for several reasons: (1) to withstand surgical implantation (e.g. suturability of arterial grafts), (2) to withstand physiological loading conditions (e.g. compression of articular cartilage and bone), (3) to maintain the required form of the tissue (e.g. controllable radial expansion and contraction of the vascular wall), and (4) to provide the correct mechanical stimuli to influence cellular activity (i.e. mechanotransduction). In addition, the structural properties of the scaffold, such as porosity and permeability, are critically important as they affect the physiological functions of the implant (e.g. cell migration, nutrient transport) as well as its biointegration (Haghpanahi and Miramini, 2008; Miramini et al., 2017; Pilliar et al., 1975).

There are a large number of variables during AM which can affect the final mechanical and structural characteristics of the implant (Thomas-Seale et al., 2018). These variables include the printing resolution, pore size, crystallinity in the melt or extrusion process, and post-processing parameters. In addition, the intrinsic properties of the raw material prior to manufacturing, particularly the viscosity and surface tension, allow the material to be printed in the first place. They also influence the final state of the construct. In the case of AM, the geometric flexibility of the technique is so extensive that the structural stiffness is a crucial influencing factor. Table 4 summarises recent literature on the mechanical characterisation of artery, cartilage, and bone AM replacements. The mechanical properties and parameters are named as per the cited literature. It is worth mentioning that in some instances authors interchange the use of lattice, mesh and porosity to accurately describe the cited research.

\section{1) Artery}

The potential of cardiovascular AM for the manufacturing of synthetic arterial grafts has been summarised in recent reviews (Duan, 2017; Elomaa and Yang, 2017; Roy et al., 2018). Differences in the relative quantities and organisation of collagen and elastin in the coronary and femoral arteries and the aorta confer different global properties that must be factored into the design parameters of the biomaterial (see Table 2). Consequently, these values act as a guide to the material scientist, such that the mechanical properties of AM materials can be engineered to match host arterial tissue, in the region of interest, to determine their viability as graft materials.

The recent advancement of FDM and SLM of thermoplastic polymers has been proposed as a solution towards 3D printed, biodegradable coronary stents (Flege et al., 2013; Guerra et al., 2018). Stents are not used to directly replace CT; rather, they are permanent or non-permanent devices which provide support to the arterial wall by widening the passageway to maintain function of diseased tissue. These materials are crucial in providing radial strength and preventing recoil. Therefore, mechanical and structural characterisation of AM stents is of interest in this review.

Both PLA and PCL are hemocompatible and demonstrate a high capacity for endothelial cell adhesion (Flege et al., 2013), whilst thermoplastic polyurethane (TPU) is inert to the components of blood (Esmaeili et al., 2019). Mechanical characterisation of these polymers is mostly limited to radial expansion, recoil, and elastic modulus. Using the design flexibility afforded by AM, radial strength and stent expandability of PLA can be optimised 
through variation of strut geometry (Flege et al., 2013). A study conducted by Guerra et al. (2018) characterised the dynamic modulus of both PLA and PCL stents (Guerra et al., 2018). Whilst PLA stents exhibit a high dynamic modulus $\left(\mathrm{E}^{\prime}=2.0 \mathrm{GPa}\right)$ and low recoil ratio, PCL constructs demonstrate a lower dynamic modulus $\left(\mathrm{E}^{\prime}=0.35 \mathrm{GPa}\right)$ but a greater capacity for fibroblast adhesion and radial expansion. Composite PCL/PLA stents look to combine the elasticity of PCL with the rigidity of PLA to mirror the heterogeneity of vascular tissue $\left(E^{\prime}=\right.$ $1.39 \mathrm{GPa}$ ). However, it is noted that these values far exceed the storage moduli reported for native arterial tissue (as shown in Table 2). Similarly, the elastic moduli of TPU/HA composite stents surpass the elastic modulus of arterial tissue (1.68-1.53 GPa compared to 0.1-2 MPa for the femoral artery) (Esmaeili et al., 2019). Nevertheless, the tensile strength ranged from 3.13.7 $\mathrm{MPa}$, which matches the tensile strength of the descending thoracic aorta (Adham et al., 1996; Chow and Zhang, 2011; O'Leary et al., 2014; Stemper et al., 2007).

Alternatively, bioinks may be used to directly replicate CT tissue. 3D printed hydrogel scaffolds possess significantly lower mechanical strength to vascular stents. Typical bioink materials for cardiovascular application include polysaccharides (chitosan, agarose, alginate) and proteins (gelatin and fibrin) (Roy et al., 2018). The hemocompatibility of these biomaterials is generally well reported; however, their mechanical integrity is less characterised. For example, the mechanical characterisation of additively manufactured gelatin-based stents is mostly limited to compression testing. $10 \%$ gelatin methacrylamide + $1 \%$ gellan gum gel printed on a custom-made BioExtruder bioprinter was compressed to $15 \%$ strain and displayed a Young's modulus of $59 \mathrm{kPa}$ (Melchels et al., 2014). The compressive moduli of bioprinted gelatin methacryloyl/poly(ethylene glycol)-tetra-acrylate (PEGTA) scaffolds at $10 \%$ strain ranged from $24.2-50.7 \mathrm{kPa}$ (Jia et al., 2016). Gelatin/microbial transglutaminase (mTG), of interest due to its ECM-like nature, was printed into the geometry of the left coronary artery using SLA and compressed to $60 \%$ strain, yielding a compressive modulus of $5 \mathrm{MPa}$ (Liu et al., 2019a).

Mechanical characterisation of arterial supports and substitutes thus far has been focused on quasi-static loading. Radial expansion and elastic moduli are most commonly reported, with a limited number of studies extending to dynamic testing. However, the mechanical properties of 3D printed stents or bioinks are rarely matched to the mechanical properties of a particular host vessel. Furthermore, the elastic modulus of the biomaterial does not reflect the nonlinearity of arterial tissue. To better mimic tissue anisotropy and thus in vivo wall performance, future studies should expand into viscoelastic characterisation and fatigue testing under repeated cyclic loading.

\section{2) Cartilage}

As shown in Fig. 11 Cartilage is highly heterogeneous and anisotropic (Armiento et al., 2018), with strain-stiffening behaviour (Zhang et al., 2015) and ultra-low friction coefficient at the contacting surface (Longmore and Gardner, 1975), achieved through complex lubrication mechanisms (Liao et al., 2019). It is extremely difficult to manufacture scaffolds that can replicate these variable properties using traditional techniques. The topological freedom offered by AM and the ability to print composite materials enables more structurally and mechanically biofidelic cartilage scaffolds to be produced. These tissue scaffolds can be printed with seed cells, drugs and growth factors which enable tissue regeneration (Cheng et al., 2019). 
Synthetic polymers like PCL and poly(vinyl acetate) (PVA) are commonly used in cartilage scaffolds because they are biocompatible and their mechanical properties can be easily tailored (Chen et al., 2014; Cheng et al., 2019; Dong et al., 2017; Woodruff and Hutmacher, 2010). These base polymers can also be combined with natural polymers such as chitosan (Dong et al., 2017) to encourage tissue regeneration, and $\beta$-TCP (Shim et al., 2017) and HA (Du et al., 2017) to encourage bone regeneration. Natural polymers can also be combined to form hydrogel scaffolds, such as silk-fibrin/gelatin (Shi et al., 2017) and gelatin methacrylate/hyaluronic acid methacrylate (Onofrillo et al., 2018).
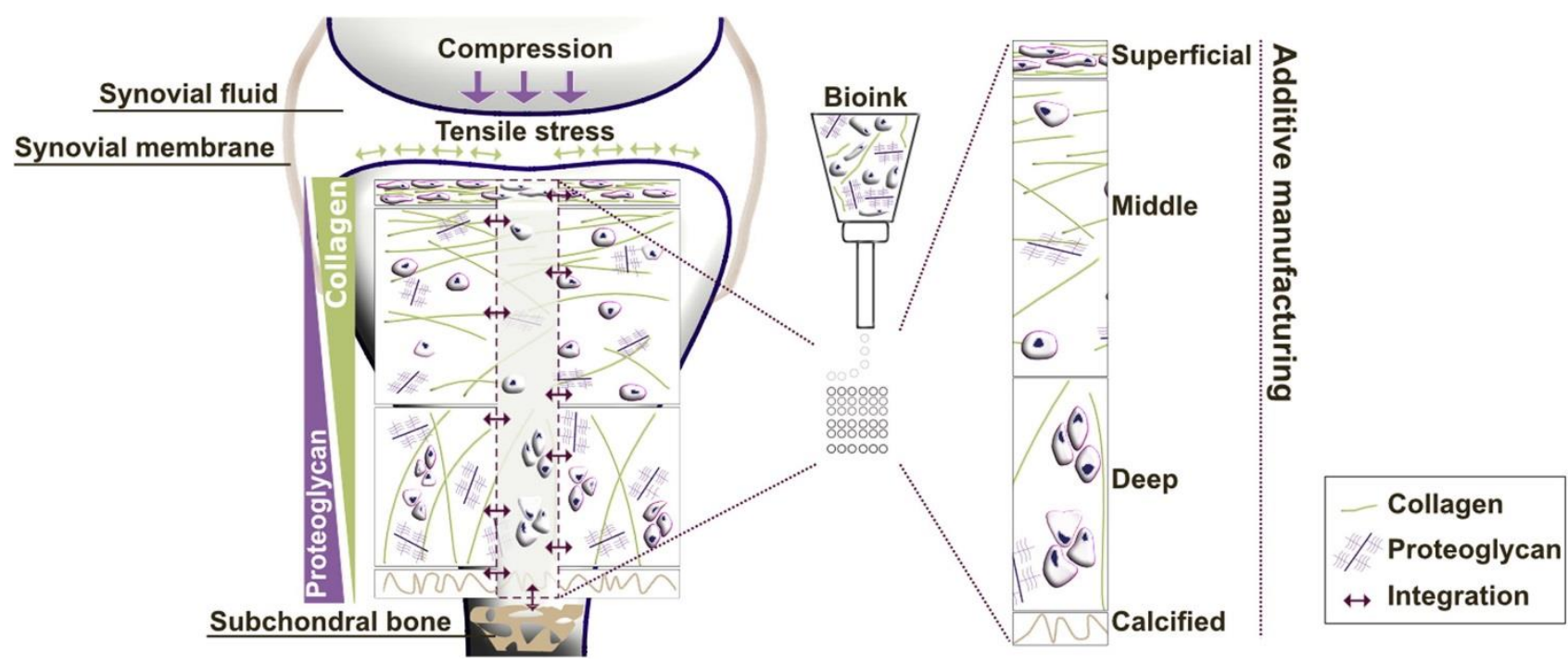

Fig. 11. Several crucial aspects of cartilage tissue need to be considered for a successful AM of cartilage including spatial and orientation dependent of cartilage tissue components, cartilage poroelastic behaviour, low friction at the opposing surfaces and attachment and integration with the host tissue. Image is reprinted from (Armiento et al., 2018) with permission from Elsevier.

There is limited literature on the mechanical characterisation of tissue scaffolds for cartilage regeneration. Most studies have focussed on compression testing to determine Young's modulus and occasionally yield stress. For instance, PLA cartilage scaffolds produced using FDM were compression tested to determine the Young's modulus. Rosenzweig et al. (2015) concluded the scaffolds were too stiff for use in tissue repair. This is typical of scaffolds produced using materials which can be printed using FDM (Shen et al., 2019). Du et al. (2017) used SLS to produce a multilayer PCL scaffold with a HA gradient increasing from articular cartilage through to subchondral bone layer. The compressive modulus and strength of the PCL/HA scaffold were reported as $8.7 \mathrm{MPa}$ and 4.6 MPa respectively. One study has used dynamic mechanical analysis to determine the compressive modulus of a poly(trimethylene carbonate) (PTMC) scaffold manufactured using SLA (Schüller-Ravoo et al., 2013). Another study has explored the use of nanoidentation to investigate the elastic modulus of a silk-fibrin and gelatin hydrogel (Shi et al., 2017). To account for the anisotropic nature of the scaffold, they took repeated measurements at different locations on the sample.

Several studies have determined the mechanical properties of the bulk hydrogel material, rather than the scaffold. Elomaa et al. (2011) and Schüller-Ravoo et al. (2013) 
conducted tensile tests on thin films to determine elastic modulus, yield strength, elongation at yield and toughness. Linzhong et al. (2010) conducted compression tests on cylinders of polyacrylamide (PAM) to determine the elastic modulus. However, the topology of the scaffold has an impact on its mechanical properties (Afshar et al., 2016). Therefore, determining the mechanical properties of the bulk material is not representative of how the scaffold will behave in vivo because it does not take into account anisotropic behaviour.

\section{3) Bone}

Reshaping the implant during surgery is not always effective to match the patient's anatomy, particularly for complex bone and joint systems such as the temporomandibular joint. Ackland et al. (2018) developed an AM prosthesis consisting of a condylar component made of titanium-64, manufactured using SLM, and a high-density polyethylene fossa fabricated using machining techniques. This prosthesis has been successfully implanted into a patient; the joint pain level was subsequently reduced to a negligible level post-operatively (Ackland et al., 2018). 3D printed osteosynthesis plates have also been effectively used for fracture fixation in orthopaedic practice and have significantly reduced the operation time (Shuang et al., 2016). This is due to the pre-operative planning and patient specific customisation of the implant, which circumvents the need to reshape the contour of the implant during surgery.

The bulk of recent literature reported on Ti-6AL-4V and its composites describes the elastic modulus and yield strength as obtained through compression testing. A selection of studies have broached fatigue testing. Whilst Elsayed et al. (2019) report a parameter specific elastic modulus of 17.12-74.98 GPa for dense specimens (associated porosity values are available in the text), the predominant volume of literature is hugely dependent on lattice topology based around the choice of unit cell.

For large bone defects, a bone graft or biodegradable scaffold is often required to promote tissue regeneration. HA is a popular material for bone scaffolds. Liu et al. (2019b) report a compressive modulus of 15.25 MPa for lattice HA scaffolds. A number of other recent studies are focussed on integrating HA into composite scaffolds. In 2015, (Vaezi and Yang) accounted that whilst PEEK is a promising material toward the replication of the elastic modulus of cortical bone, there is no literature on its mechanical properties. In (2016), Vaezi and Yang characterised the AM of HA and moulding of PEEK into a composite, reporting a compressive modulus of 1.6-2.8 GPa.

Lee et al. (2012) studied the influence of pore architecture and stacking direction on the mechanical properties of 3D printed bone tissue engineering scaffolds with blended PCL/PLGA. The results of their study showed that the compressive modulus of the scaffolds is highly influenced by the scaffold architecture. While a compressive modulus of $178 \mathrm{MPa}$ was achieved with a triangular microarchitecture, a lattice-type scaffold had a compressive modulus of 120.2 MPa. To improve the biocompatibility, osteoconductivity and degradation kinetics of PCL polymers, Shim et al. (2017) used a PCL/ $\beta$-TCP blend and 3D printed bone scaffold membrane for guided bone regeneration. The 3D printed PCL and PCL/ $\beta$-TCP wet membrane had a tensile modulus of $171 \mathrm{MPa}$ and $213 \mathrm{MPa}$ respectively. 
To summarise, for scaffolds aimed at replicating the mechanical properties of bone, studies thus far have been predominately limited to mechanical characterisation by compression testing, with examples of studies which have progressed to tensile testing and fatigue testing. 
Table 4: Characterisation Type and Variable Parameters of AM biomaterials proposed as replacements for CT

\begin{tabular}{|c|c|c|c|c|c|c|c|c|c|}
\hline \multirow{2}{*}{$\begin{array}{l}\text { Target } \\
\text { Tissue } \\
\text { Scaffold } \\
\text { Type }\end{array}$} & \multicolumn{6}{|c|}{ Manufacturing } & \multicolumn{2}{|c|}{ Mechanical Characterisation } & \multirow[b]{2}{*}{ Reference } \\
\hline & Biomaterial & $\begin{array}{l}\text { Pre-printing } \\
\text { Properties }\end{array}$ & $\begin{array}{l}\text { AM } \\
\text { Platform }\end{array}$ & $\begin{array}{l}\text { Printing } \\
\text { Parameters }\end{array}$ & $\begin{array}{l}\text { Topological } \\
\text { Design }\end{array}$ & $\begin{array}{l}\text { Post- } \\
\text { Processing }\end{array}$ & $\begin{array}{l}\text { Testing } \\
\text { Method }\end{array}$ & $\begin{array}{l}\text { Parameters } \\
\text { Characterised }\end{array}$ & \\
\hline \multirow[t]{7}{*}{$\begin{array}{l}\text { Arterial } \\
\text { Wall }\end{array}$} & PCL & N/A & FDM & Fixed & $\begin{array}{l}\text { Lattice - Fixed } \\
\text { Unit Cell }\end{array}$ & - & $\begin{array}{l}\text { Radial } \\
\text { Expansion }\end{array}$ & & $\begin{array}{l}\text { (Guerra and } \\
\text { Ciurana, 2018) }\end{array}$ \\
\hline & PLA & N/A & $\begin{array}{l}\text { FDM } \\
\text { (Ultimaker } \\
3 \\
\text { Extended } \\
\text { FDM 3D } \\
\text { Printer) } \\
\end{array}$ & Fixed & $\begin{array}{l}\text { Lattice - Fixed } \\
\text { Unit Cell }\end{array}$ & - & $\begin{array}{l}\text { Radial } \\
\text { Compression }\end{array}$ & & $\begin{array}{l}\text { (Wu et al., } \\
\text { 2018) }\end{array}$ \\
\hline & $\begin{array}{l}\text { Composite } \\
\text { PCL/PLA }\end{array}$ & N/A & FDM & $\begin{array}{l}\text { Mostly } \\
\text { fixed, } \\
\text { except } \\
\text { varied } \\
\text { printing } \\
\text { flow rate }\end{array}$ & $\begin{array}{l}\text { Lattice - } \\
\text { Variable Unit } \\
\text { Cell }\end{array}$ & - & $\begin{array}{l}\text { Radial } \\
\text { Expansion }\end{array}$ & $\begin{array}{l}\text { Dynamic } \\
\text { Storage } \\
\text { Modulus }\end{array}$ & $\begin{array}{l}\text { (Guerra et al., } \\
\text { 2018) }\end{array}$ \\
\hline & Composite TPU/HA & N/A & FDM & Fixed & Filament & - & $\begin{array}{l}\text { Elastic Modulus } \\
\text { and Tensile } \\
\text { Strength }\end{array}$ & & $\begin{array}{l}\text { (Esmaeili et al., } \\
\text { 2019) }\end{array}$ \\
\hline & GelMA/Gellan Gum & N/A & $\begin{array}{l}\text { Custom- } \\
\text { build } \\
\text { Extrusion } \\
\text { Bioprinter }\end{array}$ & Fixed & Solid/Porous & $\begin{array}{l}\text { UV } \\
\text { Radiation }\end{array}$ & $\begin{array}{l}\text { Compressive } \\
\text { Modulus }\end{array}$ & & $\begin{array}{l}\text { (Melchels et al., } \\
\text { 2014) }\end{array}$ \\
\hline & GelMA/PEGTA & N/A & $\begin{array}{l}\text { Bioprinter } \\
\text { (Novogen } \\
\text { MMX } \\
\text { Bioprinter, } \\
\text { Organovo) } \\
\end{array}$ & Fixed & Solid/Porous & $\begin{array}{l}\text { UV } \\
\text { Radiation } \\
\text { followed by } \\
\text { immersion } \\
\text { into EDTA }\end{array}$ & $\begin{array}{l}\text { Compressive } \\
\text { Modulus }\end{array}$ & & (Jia et al., 2016) \\
\hline & Gelatin/mTG & N/A & SLA & Fixed & $\begin{array}{l}\text { Mould, left } \\
\text { coronar4y } \\
\text { artery }\end{array}$ & $\begin{array}{l}\text { Storage at } 4 \\
{ }^{\circ} \mathrm{C} \text { followed } \\
\text { by } \\
\text { incubation at } \\
37^{\circ} \mathrm{C} \text { and }\end{array}$ & $\begin{array}{l}\text { Compressive } \\
\text { Modulus }\end{array}$ & & $\begin{array}{l}\text { (Liu et al., } \\
\text { 2019a) }\end{array}$ \\
\hline
\end{tabular}




\begin{tabular}{|c|c|c|c|c|c|c|c|c|c|}
\hline & & & & & & $\begin{array}{l}\text { water } \\
\text { immersion }\end{array}$ & & & \\
\hline \multirow[t]{7}{*}{ Cartilage } & PCL/HA & N/A & SLS & Various & $\begin{array}{l}\text { Functionally } \\
\text { graded, } \\
\text { multilayer } \\
\text { scaffold } \\
\end{array}$ & $\begin{array}{l}\text { Wind } \\
\text { machine to } \\
\text { remove } \\
\text { microspheres }\end{array}$ & Compression & $\begin{array}{l}\text { Compressive } \\
\text { modulus and } \\
\text { strength }\end{array}$ & (Du et al., 2017) \\
\hline & PLA & N/A & FDM & Fixed & $\begin{array}{l}\text { Lattice - Fixed } \\
\text { Unit Cell }\end{array}$ & - & Compression & $\begin{array}{l}\text { Young's } \\
\text { Modulus }\end{array}$ & $\begin{array}{l}\text { (Rosenzweig et } \\
\text { al., 2015) }\end{array}$ \\
\hline & $\begin{array}{l}\text { Stem cell laden } \\
\text { hydrogel (Gelatin } \\
\text { methacrylate and } \\
\text { Hyaluronic acid } \\
\text { methacrylate) }\end{array}$ & N/A & $\begin{array}{l}\text { In situ } \\
\text { bioprinting }\end{array}$ & Fixed & $\begin{array}{l}\text { Disc shaped } \\
\text { scaffold }\end{array}$ & UV radiation & $\begin{array}{l}\text { Atomic Force } \\
\text { Microscopy }\end{array}$ & $\begin{array}{l}\text { Compression } \\
\text { modulus }\end{array}$ & $\begin{array}{l}\text { (Onofrillo et al., } \\
\text { 2018) }\end{array}$ \\
\hline & $\begin{array}{l}\text { Silk fibrin + gelatin } \\
+ \text { stem cells }\end{array}$ & N/A & $3 \mathrm{DP}$ & Fixed & $\begin{array}{l}\text { Fixed porous } \\
\text { scaffold design }\end{array}$ & - & Nanoindentation & $\begin{array}{l}\text { Elastic } \\
\text { Modulus, } \\
\text { Reduced } \\
\text { Modulus, } \\
\text { Hardness }\end{array}$ & $\begin{array}{l}\text { (Shi et al., } \\
2017)\end{array}$ \\
\hline & PTMC & N/A & SLA & Fixed & $\begin{array}{l}\text { Fixed gyroid } \\
\text { porous scaffold } \\
\text { design }\end{array}$ & $\begin{array}{l}\text { Washed with } \\
\text { propylene } \\
\text { carbonate } \\
\text { and ethanol }\end{array}$ & $\begin{array}{l}\text { Dynamic } \\
\text { Mechanical } \\
\text { Analysis, } \\
\text { Tension on thin } \\
\text { film (bulk } \\
\text { material) }\end{array}$ & $\begin{array}{l}\text { Compressive } \\
\& \text { Tensile } \\
\text { Modulus, } \\
\text { Yield } \\
\text { Strength, } \\
\text { Elongation at } \\
\text { Yield } \\
\text { Toughness }\end{array}$ & $\begin{array}{l}\text { (Schüller-Ravoo } \\
\text { et al., 2013) }\end{array}$ \\
\hline & PCL & N/A & SLA & Fixed & $\begin{array}{l}\text { Fixed gyroid } \\
\text { porous scaffold } \\
\text { design }\end{array}$ & $\begin{array}{l}\text { Washed in } \\
\text { acetone and } \\
\text { isopropanol }\end{array}$ & $\begin{array}{l}\text { Tension on thin } \\
\text { film (bulk } \\
\text { material) }\end{array}$ & $\begin{array}{l}\text { Elastic } \\
\text { Modulus, } \\
\text { Tensile } \\
\text { Strength, } \\
\text { Elongation at } \\
\text { Break } \\
\end{array}$ & $\begin{array}{l}\text { (Elomaa et al., } \\
\text { 2011) }\end{array}$ \\
\hline & PAM & N/A & SLA & Various & $\begin{array}{l}\text { Solid with } \\
\text { internal channel } \\
\text { and 2D } \\
\text { network } \\
\text { structure }\end{array}$ & - & $\begin{array}{l}\text { Compression } \\
\text { (bulk material) }\end{array}$ & $\begin{array}{l}\text { Elastic } \\
\text { Modulus }\end{array}$ & $\begin{array}{l}\text { (Linzhong et al., } \\
2010 \text { ) }\end{array}$ \\
\hline
\end{tabular}




\begin{tabular}{|c|c|c|c|c|c|c|c|c|c|}
\hline \multirow[t]{7}{*}{ Bone } & \multirow[t]{5}{*}{ Ti-6AL-4V } & $\begin{array}{l}\text { Gas atomized } \\
\text { alloy powder, } \\
\text { grain size } 20- \\
50 \mu \mathrm{m} . \\
\text { Recycled < } \\
60 \mu \mathrm{m}\end{array}$ & $\begin{array}{l}\text { SLM } \\
\text { (Concept } \\
\text { Laser) }\end{array}$ & Fixed & $\begin{array}{l}\text { Lattice - } \\
\text { Variable Unit } \\
\text { Cell }\end{array}$ & - & $\begin{array}{l}\text { Quasi-Static } \\
\text { Compression }\end{array}$ & Fatigue & $\begin{array}{l}\text { (Burton et al., } \\
\text { 2019) }\end{array}$ \\
\hline & & - & $\begin{array}{l}\text { SLM } \\
\text { (Renishaw } \\
\text { AM250) } \\
\end{array}$ & Fixed & $\begin{array}{l}\text { Lattice - } \\
\text { Variable Unit } \\
\text { Cell }\end{array}$ & Heat-treated & Compression & $\begin{array}{l}\text { Elastic } \\
\text { Modulus and } \\
\text { Yield Strength }\end{array}$ & $\begin{array}{l}\text { (Alabort et al., } \\
\text { 2019) }\end{array}$ \\
\hline & & $\begin{array}{l}\text { Gas atomized } \\
\text { alloy powder, } \\
\text { grain size } 19- \\
45 \mu \mathrm{m}\end{array}$ & $\begin{array}{l}\text { SLM } \\
\text { (ProX } \\
100 T M)\end{array}$ & Variable & Solid/ Porous & - & Compression & $\begin{array}{l}\text { Elastic } \\
\text { Modulus and } \\
\text { Ultimate } \\
\text { Strength } \\
\end{array}$ & $\begin{array}{l}\text { (Elsayed et al., } \\
\text { 2019) }\end{array}$ \\
\hline & & $\begin{array}{l}\text { Grade } 23, \\
\text { median } \\
\text { particle size } \\
\text { of } 31.6 \mathrm{~lm}\end{array}$ & $\begin{array}{l}\text { SLM } \\
\text { (Realizer, } \\
\text { SLM-125) }\end{array}$ & Fixed & $\begin{array}{l}\text { Functional } \\
\text { grading of } \\
\text { variable lattice } \\
\text { density }\end{array}$ & - & $\begin{array}{l}\text { Quasi-Static } \\
\text { Compression }\end{array}$ & $\begin{array}{l}\text { Modulus, } \\
\text { Yield Stress, } \\
\text { Maximum } \\
\text { Stress and } \\
\text { Plateau Stress. }\end{array}$ & $\begin{array}{l}\text { (Zhang et al., } \\
\text { 2019) }\end{array}$ \\
\hline & & $\begin{array}{l}\text { Extra low } \\
\text { interstitial } \\
\text { powder } \\
\text { with a particle } \\
\text { diameter } \\
\text { range of } 15- \\
45 \mu \mathrm{m}\end{array}$ & $\begin{array}{l}\text { SLM (3D } \\
\text { systems) }\end{array}$ & Fixed & $\begin{array}{l}\text { Dog bone } \\
\text { specimens - } \\
\text { varying } \\
\text { between dense } \\
\text { and porous. }\end{array}$ & $\begin{array}{l}\text { HIP and } \\
\text { surface } \\
\text { treatments. }\end{array}$ & Tension & $\begin{array}{l}\text { Modulus, } \\
\text { Yield } \\
\text { Strength, } \\
\text { Ultimate } \\
\text { Strength, } \\
\text { Fatigue. }\end{array}$ & $\begin{array}{l}\text { (Kelly et al., } \\
\text { 2019) }\end{array}$ \\
\hline & $\begin{array}{l}\text { Hydroxyapatite } \\
\text { (HA) }\end{array}$ & $\begin{array}{l}\text { HA powder } \\
(12 \mu \mathrm{m}), \\
\text { photopolymer, } \\
\text { and dispersant } \\
\text { (Variable wt.) }\end{array}$ & $\begin{array}{l}\text { Digital } \\
\text { Light } \\
\text { Processing } \\
\text { (DLP) }\end{array}$ & Variable & Fixed Lattice & Sintering & Compression & $\begin{array}{l}\text { Modulus and } \\
\text { Strength }\end{array}$ & $\begin{array}{l}\text { (Liu et al., } \\
\text { 2019b) }\end{array}$ \\
\hline & $\begin{array}{l}\text { Composite Ti-6Al- } \\
4 \mathrm{~V}-5 \% \text { HA }\end{array}$ & $\begin{array}{l}\text { HA powder } \\
\text { and plasma } \\
\text { atomized Ti- } \\
6 \mathrm{Al}-4 \text {, with a } \\
\text { D50 of } 72 \mathrm{~m}\end{array}$ & $\begin{array}{l}\text { Electron } \\
\text { Beam } \\
\text { Melting } \\
\text { (EBM) } \\
\text { (Arcam } \\
\text { S12 EBM) }\end{array}$ & Fixed & $\begin{array}{l}\text { Solid and } \\
\text { varying mesh. }\end{array}$ & - & $\begin{array}{l}\text { Compression } \\
\text { and Tension }\end{array}$ & $\begin{array}{l}\text { Tensile Yield } \\
\text { and Ultimate } \\
\text { Stress, } \\
\text { Compressive } \\
\text { Strength, } \\
\text { Vickers } \\
\text { Hardness. }\end{array}$ & $\begin{array}{l}\text { (Terrazas et al., } \\
\text { 2019) }\end{array}$ \\
\hline
\end{tabular}




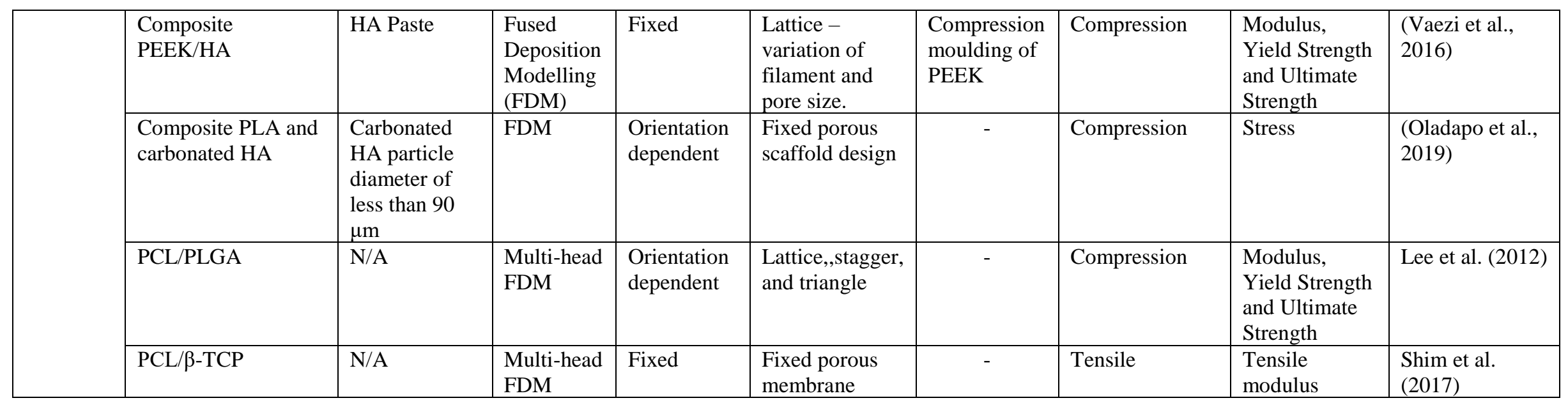




\section{6) Grand Challenges and Future Perspectives}

Despite recent advances in the AM of CT replacements, several grand challenges remain that need to be addressed before fabrication of reliable and effective implants using AM is implementable in clinical practice.

\subsection{Material Biocompatibility and Mechanical Properties}

Despite remarkable achievements in developing new biomaterials for CT replacement and temporary scaffolds, there are many issues with biocompatibility and mismatching mechanical properties that need to be addressed in order to improve implant reliability and success (Liu et al., 2018; Williams, 2019). While synthetic polymers have many advantages such as fabrication flexibility, good printability, and consistent and excellent mechanical properties, they suffer from bioinertness and consequently poor biointegration. Conversely, natural polymers have superior bioactivity and biocompatibility but demonstrate poor mechanical properties, printability, and biodegradation rate control (Li and Zreiqat, 2019). Metallic biomaterials have high corrosion and fatigue resistance and superior mechanical stiffness. However, they suffer from stiffness mismatch and poor biointegration (Miramini et al., 2014). Bioactive ceramics, on the other hand, show favourable interaction with host tissue, promoting biointegration and tissue regeneration. However, they are limited to bone regeneration due to their chemical composition and mechanical properties (Li and Zreiqat, 2019).

Comparison between Table 2 and Table 4 shows the huge disparity between the mechanical properties currently achievable via AM, and those that are required to replicate arterial tissue, cartilage, and bone. The materials are typically under-engineered and lack in depth of characterisation compared to the current status of literature surrounding characterisation of CTs. In the literature reviewed, the primary characteristics tested across all types of CT replacement biomaterials is limited to elastic modulus and yield stress. These values vastly oversimplify the viscoelasticity of native CTs, where fibre orientation within the ECM leads to heterogeneous mechanical behaviour that is, at present, not replicable or not characterised in AM replacements. In some instances, the mechanical properties of the bulk biomaterial are reported. However, the mechanical properties of the bulk material do not accurately represent the anisotropy associated with scaffold topology, and should not be used to extrapolate the mechanical properties of the AM scaffold. In addition, the impact that load directionality has on mechanical characterisation is often overlooked when characterising AM implants. For CT characterisation, this load may be applied uniaxially or biaxially, longitudinally or transversally, or at varying locations within the tissue. Ideally, AM replacements should be characterised accordingly. Finally, minimal literature exists to quantify implant response under dynamic loading, over time. Fatigue, creep, stress relaxation and wear testing of AM implants, under physiological loading conditions, must be characterised before these constructs are translated into the clinic.

\section{Improving Implant Biocompatibility using AM}

The ability of high-resolution 3D printers to fabricate a customised implant geometry (e.g. porosity), surface microscopic morphology and topography, as well as their ability to control the surface chemistry through spatially controlled composite printing, offers great 
potential for one-step implant fabrication processes with modified surfaces (i.e. surface functionalisation) to improve implant-tissue integration (Bose et al., 2018). Surface functionalisation of the implant can also be enhanced by incorporating inorganic particles in the implant material. Several 3D printing platforms can be employed to fabricate bioceramicpolymer composite scaffolds with the aim of functionalising the scaffold surface. For example, Kotlarz et al. (2018) fabricated a scaffold composed of PLGA, calcium carbonate, and amphiphilic polymers using FDM and showed that the surface wettability of PLGA was significantly increased by adding calcium carbonate and amphiphilic polymers to the PLGA matrix. Modification of the surface chemistry of the implant is also achievable through addition of bioactive molecules on the implant surface, such as by coating PLA-based scaffolds with covalently-bound collagen (Serra et al., 2013).

\section{Improving the Mechanical Properties of Implants using AM}

The topological freedom provided by AM enables the design of new biomaterials, which can solve particular challenges in replicating CTs. The use of Functionally Graded Biomaterials (FGBMs) has increased in recent years due to their ability to satisfy different and even diverse goals (Salimi Bani et al., 2017). In FGBMs, the composition or structure of the material is varied over the volume, resulting in variable properties throughout one component. AM allows for components to be manufactured from multiple materials at once and is often used to create a FGBM.

Bone tissue implants need to have a similar stiffness to the surrounding bone, in order to avoid stress shielding and to improve bone regeneration (Ganadhiepan et al., 2019a; Ghimire et al., 2019; Miramini et al., 2018; Zhang ${ }^{1}$ et al., 2013), yet they are frequently manufactured from stainless steel or titanium, which is much stiffer (Miramini et al., 2015). Many different studies have created FGBMs by varying the size of the lattice unit cell throughout the material to alter the stiffness of the scaffold in different locations (Mahbod and Asgari, 2019; Torres et al., 2016; Zhang et al., 2019). Ayatollahi et al. (2019) have proposed a 3-phase ceramic based FGBM, which uses HA, alumina or zircona, and titanium all within the same component to provide different material properties in different locations on a knee implant. The use of FGBMs is also being investigated to develop artificial blood vessels. For instance, a bioinspired numerical model has been developed with the aim to replicate the three tissue layers of the aorta by combining the elastic moduli of three polymer layers into a FGBM (Salimi Bani et al., 2017).

It is clear that FGBMs have the potential to solve some of the most prominent issues surrounding mismatching material properties for CT scaffolds. However, the material properties of a component manufactured from a FGBM will vary across the component and are dependent upon not only their bulk material properties but also their topology and the AM process used. The question therefore arises of how to fully characterise the mechanical properties of a FGBM, and how to understand the contribution that each variable makes to the resultant properties of the implant.

\subsection{Design Challenges}

The topological design dependence of the mechanical properties outlined in Table 4 can be predominately classified as a solid, porous, or lattice structure. This reflection demonstrates a limited approach to design in this research area. Lattice structures are designed 
through choice of a unit volume (cell) which is then repeated throughout the structure. Lattice structures are commonly (but not exclusively) designed using commercial software such as Simpleware (Synopsys, 2019). Other research options have been developed that offer alternative methods towards the design of porous structures (Doubrovski et al., 2015; Vidimce et al., 2016). Yet, though software options exist design for AM, designing for additive manufacturing (DfAM) remains a constraint to the progression of AM across all industries, including biomedical applications (Thomas-Seale et al., 2018).

Key issues stem from a lack of knowledge in the propagation of AM techniques and applications. Specifically, a lack of foundation engineering knowledge in subtractive technology leads to inefficient design and lack of creativity. A huge amount of literature exists on design constraints which are dependent on the process, platform, and material parameters (Kranz et al., 2015; Meisel and Williams, 2015; Webb and Doyle, 2017). This is also reflected in the parameter dependent characterisation displayed in Table 4. Literature which focused on the constraints of topology, in itself, emphasises the limitations of AM and in doing so causes additional constraints to creativity. The review by Pradel et al. (2018) maps research literature onto a framework of product design. The study highlights the important concept of validity, where some design literature is indiscriminate about whether the outcomes of a study are process or machine specific. Therefore, caution must be exercised in assuming the mechanical properties of predefined scaffolds. In the current review, a holistic approach is taken to discuss the outcomes of literature in direct reference to the variable parameters of the original study.

Assuming the capacity of the AM platform of interest is well known and defined mechanically, what options exist to increase the creativity of scaffold design? The concept of bioinspired design is a well acknowledged avenue of creativity (Barthelat, 2015; Egan et al., 2015; French, 1994). Yet, whilst the combination of bioinspired design and AM to scaffold manufacturing has been broached in the literature (Longley et al., 2018; Magin et al., 2016), its physical application remains underutilised. Murphy and Atala (2014) define the concept of biomimicry as "the replication of biological tissues on the microscale" (Murphy and Atala, 2014a). Rosen (2007) implements this theory into the conceptual design stage of research that progresses onto the design of cellular structures (Rosen, 2007). Another emerging area of bioinspired design is the topological design of interfacing materials, which in turn allows the design of interlocking heterogeneous materials. This concept is demonstrated by Barthelat et al. who explore the computational modelling and experimental testing of the AM of bioinspired interlocking materials (Malik et al., 2017; Mirkhalaf and Barthelat, 2017).

\subsection{Printability, Cell Viability, Printer Resolution and Speed}

Ideally, biomaterial 3D printers should be able to reliably deliver a precise (high resolution), accurate, and reasonably quick fabrication process. In the case of bioprinting, high cell viability is also necessitated. However, at present, there are numerous challenges to overcome in order to achieve these aims. As outlined in Table 1, high resolution printers are either relatively slow or they suffer from long preparation times. For example, the bioprinting process of a small organ such as a mouse liver (with $1.3 \times 10^{8}$ cells per gram) take several hours (Ozbolat and Yu, 2013) while a slow bioprinting speed can negatively affect the cell viability (Derakhshanfar et al., 2018). In addition, high resolution printers are limited to specific biomaterial types. For example, photocrosslinkable substrates are a prerequisite for DLP. Furthermore, high resolution bioprinting generally requires bioinks with low cell density, 
and they deliver lower cell viability after printing (Liu et al., 2018; Murphy and Atala, 2014b). On the other hand, the gelation mechanism of bioinks used in bioprinters must be cytocompatible to ensure cell viability following printing and crosslinking (Das et al., 2015).

\subsection{Angiogenesis and Tissue Biomimicry}

Developing functional CT replacements requires incorporation and regeneration of different tissue types, including vasculature and nerves. One of the biggest challenges in the field of bioprinting is developing functionally-vascularised tissues, in a reasonably short time frame, to ensure cell survival and in vivo biointegration for timely tissue regeneration (Jia et al., 2016; Murphy and Atala, 2014b). The capability of AM to deposit a variety of biomaterials, cells, and biomolecules in a spatially controlled manner offers a promising yet challenging approach for CT biomimicry in regenerative medicine. For example, a recent proof-of-concept study using microextrusion bioprinting demonstrated the ability to fabricate small-scale, cellularised human hearts with major blood vessels. Crucially, personalised bioink was formulated by extracting and processing human omentum tissue and mixing with reprogrammed omental cells (Noor et al., 2019). The study received global media coverage, and presents a vital step towards the manufacturing of vascularised implants. However, the vasculature developed in this work and in similar studies is still limited to large and major blood vessels. More advanced 3D printing technology is needed to print small calibre arterial tissue. More importantly, the 3D printed heart construct is far from functional and has no contraction capacity.

\subsection{Commercialisation and Regulatory Issues}

Medical devices must meet regulations in order to ensure their safety and efficacy. In the USA the Center for Devices and Radiological Health (CDRH) at the Food and Drug Administration (FDA) approves medical devices, and in the EU devices must meet the new Medical Device Regulations, Council Regulation 2017/745/EU (Council of the European Union, 2017) and achieve CE marking. Medical devices are classified according to the risk to a patient's health under intended use and the level of controls necessary to ensure the safety and efficacy of the device. Within the FDA, devices are categorised as Class I, II, or III; in the EU, they are categorised as Class I, IIa, IIb, or III, with Class III having the highest level of risk and therefore regulation. Unless the use of AM presents a new question over the safety or effectiveness of a device, the FDA will typically classify it into the same class as other devices of that type, regardless of manufacturing method (Di Prima et al., 2016).

The custom nature of patient-specific devices produced using AM presents a regulatory challenge. The FDA does not usually consider patient specific devices to be custom devices, exempt under Section 520(b) of the Federal Food, Drug and Cosmetic Act (United States Congress, 2011; US Food and Drug Administration, 2014). Instead, they must follow the usual 510k pathway where they are treated as "envelope" submissions, where the entire design envelope, or the range of each variable, is approved. The EU is currently transitioning from the Medical Device Directive 93/42 (Council of the European Union, 1993) to the Medical Device Regulations 2017/745 (Council of the European Union, 2017), which all medical devices must meet by May 2020. Under the Medical Device Directive, the majority of patient-specific devices produced using AM were treated as custom-made devices, which did not have to be 
CE marked but did have to meet the relevant Annexes of the Directive and be prescribed by a medical practitioner. However, under the new Medical Device Regulations, mass-produced medical device products which are adapted to the specific requirements of a patient are excluded from the definition of a custom-made device. There is some debate about the definition of "mass produced" and how this will be interpreted, but there is a risk that some AM patient-specific devices will no longer be considered as custom-made and will be subject to the $\mathrm{CE}$ marking process.

AM devices must comply with the same Quality Management Systems and Good Manufacturing Practice requirements as devices manufactured in other ways. For example, the raw materials must be homogeneous, uncontaminated and traceable, and the build environment and processing parameters must be consistent between builds (Morrison et al., 2015). The location and orientation of the component on the build platform affects the mechanical properties of the component, so this must also be consistent between builds (Soe et al., 2013). AM devices usually require post-manufacture cleaning to remove support material or residual monomers. Complete removal can be difficult to achieve due to complicated geometrical features but is vital if the material is not biocompatible.

\subsection{Future Perspectives}

As the wider field of AM continues to expand rapidly, so too will the use of AM in the development of replacement materials for CT and tissue engineered scaffolds. In the next 5 to 10 years, new biocompatible materials and AM fabrication methods will be developed, which will open up new opportunities for implants and tissue constructs to better replicate the properties of CTs.

In the last decade, there has been a substantial advancement in the bioprinting of 3D tissue engineered scaffolds and this is expected to continue. These scaffolds can be used as disease models to understand how a disease progresses and to test potential treatment options. Traditional animal models and in-vitro cell cultures are unable to fully replicate the key characteristics of human physiology (Memic et al., 2017). Bioprinted organoids have been developed, which are 3D functional units derived from stem cells, which replicate the physiology of the full organ (Huch et al., 2017; Rowe and Daley, 2019). However, as discussed above, functional, life sized organs still require significant development before being translated into clinical practice, and it is predicted that this will not be achieved within the next ten years (Jiang et al., 2017).

As the cost of hardware reduces and software is developed which better assists design for AM (DfAM), point of care 3D printing in hospitals will increase and become more common place. Hospitals are increasing their investment in 3D printing, with some scaling up smaller labs into larger 3D printing facilities, which can serve a wider range of clinical needs. Point of care 3D printing is frequently used for patient-specific anatomical models for surgical planning, surgical guides and instruments (Christensen and Rybicki, 2017). By manufacturing them in the hospital, they can be produced faster and cheaper than if they were outsourced to a contract manufacturer, and there is also direct interaction with clinicians (Lanzarone et al., 2019). This in turn will lead to improved patient outcomes, and reduced waiting and operation times.

\section{7) Conclusions}


Connective tissue is characterised by a large amount of ECM and low number of cells. This can make the emphasis of the challenges required to replicate other tissues such as muscle, less stringent. Nevertheless, CT scaffolds must still replicate the properties of the host tissue to restore the mechanical and physiological function of the tissue. The acceleration of AM translates to rapid development of materials and platforms, however the discrepancy between the mechanical properties of CT and CT replacement via AM still remains large. The parameters and topological capacity of AM give rise to a large set of potential materials and design variables, towards the end goal of replicating in-vivo mechanical behaviour. Yet, the depth of the characterisation literature demonstrated for AM replacement CT is highly inadequate when directly compared to a summary of the literature on the mechanical characterisation of tissue, specifically for this review: arterial, cartilage and bone. Whilst new biomaterial development for AM is required, this is compounded by the requirement for more advanced characterisation. Additional options, such as design and design for materials, which utilise current materials and platforms may be considered to bridge the gap between the mechanical properties for current synthetic AM replacements and in-vivo CT.

\section{Acknowledgement}

The authors would like to thank the University of Melbourne and the University of Birmingham for their support. In addition, authors Saeed Miramini and Lihai Zhang acknowledge funding from the Australian Research $\mathrm{Hub}$ for Nanoscience-based Construction Material Manufacturing (ARC IH150100006). Further, author Katie L. Fegan gratefully acknowledges financial support from the EPSRC through a studentship from the Physical Sciences for Health Centre for Doctoral Training (EP/L016346/1). Author N.C. Green received funding from the EPSRC Impact Acceleration Account (EP/R11651/1) in association with the EPSRC project "Challenging the forms of bias in physical science and engineering research" (EP/SO11927/1).

\section{References}

Ackland, D., Robinson, D., Lee, P.V.S., Dimitroulis, G., 2018. Design and clinical outcome of a novel 3D-printed prosthetic joint replacement for the human temporomandibular joint. Clinical Biomechanics 56, 52-60.

Adham, M., Gournier, J.-P., Favre, J.-P., De La Roche, E., Ducerf, C., Baulieux, J., Barral, X., Pouyet, M., 1996. Mechanical characteristics of fresh and frozen human descending thoracic aorta. Journal of Surgical Research 64, 32-34.

Afshar, M., Anaraki, A.P., Montazerian, H., Kadkhodapour, J., 2016. Additive manufacturing and mechanical characterization of graded porosity scaffolds designed based on triply periodic minimal surface architectures. Journal of the mechanical behavior of biomedical materials 62, 481-494. Ahlgren, Å.R., Åstrand, H., Sandgren, T., Vernersson, E., Sonesson, B.n., Lüne, T., 2001. Dynamic behaviour of the common femoral artery: age and gender of minor importance. Ultrasound in medicine \& biology 27, 181-188.

Alabort, E., Barba, D., Reed, R.C., 2019. Design of metallic bone by additive manufacturing. Scripta Materialia 164, 110-114. 
Alfonso, M., Cymberknop, L.J., Suárez, D., Castillo, F.G., Armentano, R.L., 2016. Elastic mismatch between ePTFE and PLLA vascular grafts in relation to femoral and carotid arteries in humans: in vivo, in vitro and in silico assessment. Health and Technology 6, 181-187.

Arcaute, K., Mann, B., Wicker, R., 2010. Stereolithography of spatially controlled multi-material bioactive poly (ethylene glycol) scaffolds. Acta biomaterialia 6, 1047-1054.

Arcaute, K., Mann, B.K., Wicker, R.B., 2006. Stereolithography of three-dimensional bioactive poly (ethylene glycol) constructs with encapsulated cells. Ann. Biomed. Eng. 34, 1429-1441.

Armiento, A., Stoddart, M., Alini, M., Eglin, D., 2018. Biomaterials for articular cartilage tissue engineering: Learning from biology. Acta biomaterialia 65, 1-20.

Armstrong, C., Mow, V., 1982. Variations in the intrinsic mechanical properties of human articular cartilage with age, degeneration, and water content. The Journal of bone and joint surgery. American volume 64, 88-94.

Asghari, F., Samiei, M., Adibkia, K., Akbarzadeh, A., Davaran, S., 2017. Biodegradable and biocompatible polymers for tissue engineering application: a review. Artificial cells, nanomedicine, and biotechnology 45, 185-192.

Ashammakhi, N., Hasan, A., Kaarela, O., Byambaa, B., Sheikhi, A., Gaharwar, A.K.,

Khademhosseini, A., 2019. Advancing frontiers in bone bioprinting. Advanced healthcare materials 8, 1801048.

Aspden, R., Hukins, D., 1990. Stress in collagen fibrils of articular cartilage calculated from their measured orientations. Matrix 9, 486-488.

Athanasiou, K., Rosenwasser, M., Buckwalter, J., Malinin, T., Mow, V.C., 1991. Interspecies comparisons of in situ intrinsic mechanical properties of distal femoral cartilage. Journal of Orthopaedic Research 9, 330-340.

Athanasiou, K.A., Darling, E.M., Hu, J.C., DuRaine, G.D., Reddi, A.H., 2013. Articular Cartilage. CRC Press, Taylor \& Francis Group.

Ayatollahi, M.R., Davari, M.H., Shirazi, H.A., Asnafi, A., 2019. To Improve Total Knee Prostheses Performance Using Three-Phase Ceramic-Based Functionally Graded Biomaterials. 6.

Babilotte, J., Guduric, V., Le Nihouannen, D., Naveau, A., Fricain, J.C., Catros, S., 2019. 3D printed polymer-mineral composite biomaterials for bone tissue engineering: Fabrication and characterization. Journal of Biomedical Materials Research Part B: Applied Biomaterials.

Barthelat, F., 2015. Architectured materials in engineering and biology: fabrication, structure, mechanics and performance. International Materials Reviews 60, 413-430.

Benetos, A., Laurent, S., Hoeks, A., Boutouyrie, P., Safar, M., 1993. Arterial alterations with aging and high blood pressure. A noninvasive study of carotid and femoral arteries. Arteriosclerosis and thrombosis: a journal of vascular biology 13, 90-97.

Bergel, D., 1961. The static elastic properties of the arterial wall. The Journal of physiology 156, 445457.

Bertol, L.S., Júnior, W.K., da Silva, F.P., Aumund-Kopp, C., 2010. Medical design: direct metal laser sintering of Ti-6Al-4V. Materials \& Design 31, 3982-3988.

Bonfield, W., Clarke, E.A., 1973. Elastic deformation of compact bone. Journal of Materials Science 8, 1590-1594.

Bose, S., Robertson, S.F., Bandyopadhyay, A., 2018. Surface modification of biomaterials and biomedical devices using additive manufacturing. Acta biomaterialia 66, 6-22.

Buehler, M.J., Wong, S.Y., 2007. Entropic elasticity controls nanomechanics of single tropocollagen molecules. Biophysical journal 93, 37-43.

Burgin, L.V., Aspden, R.M., 2008. Impact testing to determine the mechanical properties of articular cartilage in isolation and on bone. Journal of Materials Science: Materials in Medicine 19, 703-711. Burton, H.E., Eisenstein, N.M., Lawless, B.M., Jamshidi, P., Segarra, M.A., Addison, O., Shepherd, D.E.T., Attallah, M.M., Grover, L.M., Cox, S.C., 2019. The design of additively manufactured lattices to increase the functionality of medical implants. Materials Science and Engineering: C 94, 901-908. Burton, H.E., Espino, D.M., 2019. The Effect of Mechanical Overloading on Surface Roughness of the Coronary Arteries. Applied bionics and biomechanics 2019.

Burton, H.E., Freij, J.M., Espino, D.M., 2017. Dynamic viscoelasticity and surface properties of porcine left anterior descending coronary arteries. Cardiovascular engineering and technology 8, 4156. 
Butscher, A., Bohner, M., Hofmann, S., Gauckler, L., Müller, R., 2011. Structural and material approaches to bone tissue engineering in powder-based three-dimensional printing. Acta biomaterialia 7, 907-920.

Cao, T., Ho, K.-H., Teoh, S.-H., 2003. Scaffold design and in vitro study of osteochondral coculture in a three-dimensional porous polycaprolactone scaffold fabricated by fused deposition modeling. Tissue engineering 9, 103-112.

Carter, D.R., Caler, W.E., Spengler, D.M., Frankel, V.H., 1981. Fatigue behavior of adult cortical bone: the influence of mean strain and strain range. Acta Orthopaedica Scandinavica 52, 481-490. Carter, D.R., Hayes, W.C., 1977. The compressive behavior of bone as a two-phase porous structure. The Journal of bone and joint surgery. American volume 59, 954-962.

Chan, V., Zorlutuna, P., Jeong, J.H., Kong, H., Bashir, R., 2010. Three-dimensional photopatterning of hydrogels using stereolithography for long-term cell encapsulation. Lab on a Chip 10, 2062-2070. Chen, C.H., Lee, M.Y., Shyu, V.B., Chen, Y.C., Chen, C.T., Chen, J.P., 2014. Surface modification of polycaprolactone scaffolds fabricated via selective laser sintering for cartilage tissue engineering. Materials science \& engineering. C, Materials for biological applications 40, 389-397.

Chen, H., Slipchenko, M.N., Liu, Y., Zhao, X., Cheng, J.-X., Lanir, Y., Kassab, G.S., 2013. Biaxial deformation of collagen and elastin fibers in coronary adventitia. Journal of applied physiology 115, 1683-1693.

Chen, Z., Li, Z., Li, J., Liu, C., Liu, C., Li, Y., Wang, P., Yi, H., Lao, C., Yuelong, F., 2018. 3D printing of ceramics: A review. Journal of the European Ceramic Society.

Cheng, A., Schwartz, Z., Kahn, A., Li, X., Shao, Z., Sun, M., Ao, Y., Boyan, B.D., Chen, H., 2019. Advances in Porous Scaffold Design for Bone and Cartilage Tissue Engineering and Regeneration. Tissue engineering. Part B, Reviews 25, 14-29.

Chia, H.N., Wu, B.M., 2015. Recent advances in 3D printing of biomaterials. J. Biol. Eng. 9, 4. Chow, M.-J., Zhang, Y., 2011. Changes in the mechanical and biochemical properties of aortic tissue due to cold storage. Journal of Surgical Research 171, 434-442.

Christensen, A., Rybicki, F.J.J.D.P.i.M., 2017. Maintaining safety and efficacy for 3D printing in medicine. 3,1 .

Claes, E., Atienza, J., Guinea, G., Rojo, F., Bernal, J., Revuelta, J., Elices, M., 2010. Mechanical properties of human coronary arteries, 2010 Annual International Conference of the IEEE

Engineering in Medicine and Biology. IEEE, pp. 3792-3795.

Council of the European Union, 1993. Council Directive 93/42/EEC of 14 June 1993 concerning medical devices, OJ No L 169/1.

Council of the European Union, 2017. Council Regulation 2017/745 of 5 April 2017 concerning medical devices, OJ No L 117/1.

Cui, X., Boland, T., DD'Lima, D., K Lotz, M., 2012. Thermal inkjet printing in tissue engineering and regenerative medicine. Recent patents on drug delivery \& formulation 6, 149-155.

Cui, X., Dean, D., Ruggeri, Z.M., Boland, T., 2010. Cell damage evaluation of thermal inkjet printed Chinese hamster ovary cells. Biotechnology and bioengineering 106, 963-969.

Das, S., Pati, F., Choi, Y.-J., Rijal, G., Shim, J.-H., Kim, S.W., Ray, A.R., Cho, D.-W., Ghosh, S., 2015. Bioprintable, cell-laden silk fibroin-gelatin hydrogel supporting multilineage differentiation of stem cells for fabrication of three-dimensional tissue constructs. Acta biomaterialia 11, 233-246.

Dawood, A., Marti, B.M., Sauret-Jackson, V., Darwood, A., 2015. 3D printing in dentistry. British dental journal 219, 521.

De Maria, C., De Acutis, A., Vozzi, G., 2015. Indirect rapid prototyping for tissue engineering, Essentials of 3D Biofabrication and Translation. Elsevier, pp. 153-164.

Dean, D., Mott, E., Luo, X., Busso, M., Wang, M.O., Vorwald, C., Siblani, A., Fisher, J.P., 2014. Multiple initiators and dyes for continuous Digital Light Processing (cDLP) additive manufacture of resorbable bone tissue engineering scaffolds: A new method and new material to fabricate resorbable scaffold for bone tissue engineering via continuous Digital Light Processing. Virtual and Physical Prototyping 9, 3-9.

Dean, D., Wallace, J., Siblani, A., Wang, M.O., Kim, K., Mikos, A.G., Fisher, J.P., 2012. Continuous digital light processing (cDLP): Highly accurate additive manufacturing of tissue engineered bone scaffolds: This paper highlights the main issues regarding the application of Continuous Digital Light 
Processing (cDLP) for the production of highly accurate PPF scaffolds with layers as thin as $60 \mu \mathrm{m}$ for bone tissue engineering. Virtual and physical prototyping 7, 13-24.

Derakhshanfar, S., Mbeleck, R., Xu, K., Zhang, X., Zhong, W., Xing, M., 2018. 3D bioprinting for biomedical devices and tissue engineering: A review of recent trends and advances. Bioactive materials 3, 144-156.

Di Prima, M., Coburn, J., Hwang, D., Kelly, J., Khairuzzaman, A., Ricles, L.J.D.P.i.M., 2016. Additively manufactured medical products - the FDA perspective. 2, 1.

Dizon, J.R.C., Espera Jr, A.H., Chen, Q., Advincula, R.C., 2018. Mechanical characterization of 3Dprinted polymers. Additive Manufacturing 20, 44-67.

Dong, L., Wang, S.J., Zhao, X.R., Zhu, Y.F., Yu, J.K., 2017. 3D- Printed Poly(epsilon-caprolactone) Scaffold Integrated with Cell-laden Chitosan Hydrogels for Bone Tissue Engineering. Scientific reports 7,13412 .

Doubrovski, E.L., Tsai, E.Y., Dikovsky, D., Geraedts, J.M.P., Herr, H., Oxman, N., 2015. Voxelbased fabrication through material property mapping: A design method for bitmap printing. Comput Aided Design 60, 3-13.

Du, Y., Liu, H., Yang, Q., Wang, S., Wang, J., Ma, J., Noh, I., Mikos, A.G., Zhang, S., 2017. Selective laser sintering scaffold with hierarchical architecture and gradient composition for osteochondral repair in rabbits. Biomaterials 137, 37-48.

Duan, B., 2017. State-of-the-art review of 3D bioprinting for cardiovascular tissue engineering. Annals of biomedical engineering 45, 195-209.

Duan, B., Hockaday, L.A., Kang, K.H., Butcher, J.T., 2013. 3D bioprinting of heterogeneous aortic valve conduits with alginate/gelatin hydrogels. Journal of biomedical materials research Part A 101, 1255-1264.

Egan, P., Sinko, R., LeDuc, P.R., Keten, S., 2015. The role of mechanics in biological and bioinspired systems. Nature Communications 6.

Elomaa, L., Teixeira, S., Hakala, R., Korhonen, H., Grijpma, D.W., Seppälä, J.V., 2011. Preparation of poly ( $\varepsilon$-caprolactone)-based tissue engineering scaffolds by stereolithography. Acta biomaterialia 7 , 3850-3856.

Elomaa, L., Yang, Y.P., 2017. Additive manufacturing of vascular grafts and vascularized tissue constructs. Tissue Engineering Part B: Reviews 23, 436-450.

Elsayed, M., Ghazy, M., Youssef, Y., Essa, K., 2019. Optimization of SLM process parameters for Ti6A14V medical implants. Rapid Prototyping Journal 25, 433-447.

Esmaeili, S., Shahali, M., Kordjamshidi, A., Torkpoor, Z., Namdari, F., Samandari, S.S., Ghadiri Nejad, M., Khandan, A., 2019. An artificial blood vessel fabricated by 3D printing for pharmaceutical application. Nanomedicine Journal 6, 183-194.

Espino, D.M., Shepherd, D.E., Hukins, D.W., 2012. Frequency dependent viscoelastic properties of knee articular cartilage. Journal of Biomechanics, S158.

Fell, N.L., Lawless, B.M., Cox, S.C., Cooke, M.E., Eisenstein, N.M., Shepherd, D.E., Espino, D.M., 2019. The role of subchondral bone, and its histomorphology, on the dynamic viscoelasticity of cartilage, bone and osteochondral cores. Osteoarthritis and cartilage 27, 535-543.

Fick, J.M., Espino, D.M., 2011. Articular cartilage surface rupture during compression: investigating the effects of tissue hydration in relation to matrix health. Journal of the mechanical behavior of biomedical materials 4, 1311-1317.

Fick, J.M., Espino, D.M., 2012. Articular cartilage surface failure: an investigation of the rupture rate and morphology in relation to tissue health and hydration. Proceedings of the Institution of

Mechanical Engineers, Part H: Journal of Engineering in Medicine 226, 389-396.

Fischer, G.M., Llaurado, J.G., 1966. Collagen and elastin content in canine arteries selected from functionally different vascular beds. Circulation research 19, 394-399.

Flege, C., Vogt, F., Höges, S., Jauer, L., Borinski, M., Schulte, V.A., Hoffmann, R., Poprawe, R., Meiners, W., Jobmann, M., 2013. Development and characterization of a coronary polylactic acid stent prototype generated by selective laser melting. Journal of Materials Science: Materials in Medicine 24, 241-255.

Fratzl, P., Misof, K., Zizak, I., Rapp, G., Amenitsch, H., Bernstorff, S., 1998. Fibrillar structure and mechanical properties of collagen. Journal of structural biology 122, 119-122. 
Freij, J.M., Burton, H.E., Espino, D.M., 2019. Objective uniaxial identification of transition points in non-linear materials: sample application to porcine coronary arteries and the dependency of their preand post-transitional moduli with position. Cardiovascular engineering and technology 10, 61-68.

French, M., 1994. Invention and Evolution: Design in Nature and Engineering. Cambridge University Press, Cambridge, UK.

Ganadhiepan, G., Miramini, S., Patel, M., Mendis, P., Zhang, L., 2019a. Bone fracture healing under Ilizarov fixator: Influence of fixator configuration, fracture geometry, and loading. International journal for numerical methods in biomedical engineering 35, e3199.

Ganadhiepan, G., Zhang, L., Miramini, S., Mendis, P., Patel, M., Ebeling, P., Wang, Y., 2019b. The effects of dynamic loading on bone fracture healing under Ilizarov Circular Fixators. Journal of biomechanical engineering 141, 051005.

Gao, C., Yang, B., Hu, H., Liu, J., Shuai, C., Peng, S., 2013. Enhanced sintering ability of biphasic calcium phosphate by polymers used for bone scaffold fabrication. Materials Science and Engineering: C 33, 3802-3810.

Gao, G., Huang, Y., Schilling, A.F., Hubbell, K., Cui, X., 2018. Organ bioprinting: are we there yet? Advanced healthcare materials 7.

Ghimire, S., Miramini, S., Richardson, M., Mendis, P., Zhang, L., 2018. Role of Dynamic Loading on Early Stage of Bone Fracture Healing. Ann. Biomed. Eng. 46, 1768-1784.

Ghimire, S., Miramini, S., Richardson, M., Mendis, P., Zhang, L., 2019. Effects of dynamic loading on fracture healing under different locking compression plate configurations: A finite element study. Journal of the mechanical behavior of biomedical materials 94, 74-85.

Ghosh, S., Parker, S.T., Wang, X., Kaplan, D.L., Lewis, J.A., 2008. Direct-write assembly of microperiodic silk fibroin scaffolds for tissue engineering applications. Advanced Functional Materials 18, 1883-1889.

Gibson, L.J., 1985. The mechanical behaviour of cancellous bone. Journal of biomechanics 18, 317328.

Goh, K., Aspden, R., Mathias, K., Hukins, D., 1999. Effect of fibre shape on the stresses within fibres in fibre-reinforced composite materials. Proceedings of the Royal Society of London. Series A:

Mathematical, Physical and Engineering Sciences 455, 3351-3361.

Goh, K., Aspden, R.M., Hukins, D.W.L., 2004. finite element analysis of stress transfer in short-fibre composite materials. Composites Science and Technology 64, 1091-1100.

Goh, K., Hukins, D., Aspden, R.M., 2003. Critical length of collagen fibrils in extracellular matrix. Journal of theoretical biology 223, 259-261.

Gokuldoss, P.K., Kolla, S., Eckert, J., 2017. Additive manufacturing processes: Selective laser melting, electron beam melting and binder jetting-Selection guidelines. Materials 10, 672.

Gopinathan, J., Noh, I., 2018. Recent trends in bioinks for 3D printing. Biomaterials research 22, 11. Grassi, L., Schileo, E., Boichon, C., Viceconti, M., Taddei, F., 2014. Comprehensive evaluation of PCA-based finite element modelling of the human femur. Medical engineering \& physics 36, 12461252.

Grassi, L., Schileo, E., Taddei, F., Zani, L., Juszczyk, M., Cristofolini, L., Viceconti, M., 2012. Accuracy of finite element predictions in sideways load configurations for the proximal human femur. Journal of biomechanics 45, 394-399.

Groenink, M., Langerak, S.E., Vanbavel, E., van der Wall, E.E., Mulder, B.J., van der Wal, A.C., Spaan, J.A., 1999. The influence of aging and aortic stiffness on permanent dilation and breaking stress of the thoracic descending aorta. Cardiovascular research 43, 471-480.

Guerra, A., Cano, P., Rabionet, M., Puig, T., Ciurana, J., 2018. 3D-Printed PCL/PLA Composite Stents: Towards a New Solution to Cardiovascular Problems. Materials 11, 1679.

Guerra, A.J., Ciurana, J., 2018. 3D-printed bioabsordable polycaprolactone stent: The effect of process parameters on its physical features. Materials \& Design 137, 430-437.

Guillotin, B., Souquet, A., Catros, S., Duocastella, M., Pippenger, B., Bellance, S., Bareille, R., Rémy, M., Bordenave, L., Amédée, J., 2010. Laser assisted bioprinting of engineered tissue with high cell density and microscale organization. Biomaterials 31, 7250-7256.

Guvendiren, M., Molde, J., Soares, R.M., Kohn, J., 2016. Designing biomaterials for 3D printing. ACS biomaterials science \& engineering 2, 1679-1693. 
Haghpanahi, M., Miramini, S., 2008. Extraction of morphological parameters of tissue engineering scaffolds using two-point correlation function, Proceedings of the 6th IASTED International Conference on Biomedical Engineering, Austria.

Hamilton, A.J., Kim, H., Nagaraj, A., Mun, J.-H., Yan, L.L., Roth, S.I., McPherson, D.D., Chandran, K.B., 2005. Regional material property alterations in porcine femoral arteries with atheroma development. Journal of biomechanics 38, 2354-2364.

Han, L., Frank, E.H., Greene, J.J., Lee, H.-Y., Hung, H.-H.K., Grodzinsky, A.J., Ortiz, C., 2011. Time-dependent nanomechanics of cartilage. Biophysical journal 100, 1846-1854.

Helgason, B., Perilli, E., Schileo, E., Taddei, F., Brynjólfsson, S., Viceconti, M., 2008. Mathematical relationships between bone density and mechanical properties: a literature review. Clinical biomechanics 23, 135-146.

Hodge, W., Carlson, K., Fijan, R., Burgess, R., Riley, P., Harris, W., Mann, R., 1989. Contact pressures from an instrumented hip endoprosthesis. JBJS 71, 1378-1386.

Holzapfel, G.A., Gasser, T.C., Ogden, R.W., 2000. A new constitutive framework for arterial wall mechanics and a comparative study of material models. Journal of elasticity and the physical science of solids $61,1-48$.

Holzapfel, G.A., Sommer, G., Gasser, C.T., Regitnig, P., 2005. Determination of layer-specific mechanical properties of human coronary arteries with nonatherosclerotic intimal thickening and related constitutive modeling. American Journal of Physiology-Heart and Circulatory Physiology 289, H2048-H2058.

Hong, D., Chou, D.-T., Velikokhatnyi, O.I., Roy, A., Lee, B., Swink, I., Issaev, I., Kuhn, H.A., Kumta, P.N., 2016. Binder-jetting 3D printing and alloy development of new biodegradable Fe-Mn$\mathrm{Ca} / \mathrm{Mg}$ alloys. Acta biomaterialia 45, 375-386.

Hopp, B., Smausz, T., Kresz, N., Barna, N., Bor, Z., Kolozsvári, L., Chrisey, D.B., Szabó, A., Nógrádi, A., 2005. Survival and proliferative ability of various living cell types after laser-induced forward transfer. Tissue Eng. 11, 1817-1823.

Hsu, S.h., Yen, H.J., Tseng, C.S., Cheng, C.S., Tsai, C.L., 2007. Evaluation of the growth of chondrocytes and osteoblasts seeded into precision scaffolds fabricated by fused deposition manufacturing. Journal of Biomedical Materials Research Part B: Applied Biomaterials: An Official Journal of The Society for Biomaterials, The Japanese Society for Biomaterials, and The Australian Society for Biomaterials and the Korean Society for Biomaterials 80, 519-527.

Huch, M., Knoblich, J.A., Lutolf, M.P., Martinez-Arias, A., 2017. The hope and the hype of organoid research. 144, 938-941.

Hukins, D., Aspden, R., Yarker, Y., 1984. Fibre reinforcement and mechanical stability in articular cartilage. Engineering in medicine 13, 153-156.

Hukins, D.L., Leahy, J., Mathias, K., 1999. Biomaterials: defining the mechanical properties of natural tissues and selection of replacement materials. Journal of Materials Chemistry 9, 629-636. Hukins, D.W., Aspden, R.M., 1985. Composition and properties of connective tissues. Trends in Biochemical Sciences 10, 260-264.

Ige, O.O., Umoru, L.E., Aribo, S., 2012. Natural products: A minefield of biomaterials. ISRN Materials Science 2012.

Iliopoulos, D.C., Kritharis, E.P., Giagini, A.T., Papadodima, S.A., Sokolis, D.P., 2009. Ascending thoracic aortic aneurysms are associated with compositional remodeling and vessel stiffening but not weakening in age-matched subjects. The Journal of thoracic and cardiovascular surgery 137, 101-109. Inoguchi, H., Kwon, I.K., Inoue, E., Takamizawa, K., Maehara, Y., Matsuda, T., 2006. Mechanical responses of a compliant electrospun poly (L-lactide-co- $\varepsilon$-caprolactone) small-diameter vascular graft. Biomaterials 27, 1470-1478.

Jaber, H., Kovacs, T., 2019. Selective laser melting of Ti alloys and hydroxyapatite for tissue engineering: progress and challenges. Materials Research Express.

Jarrahi, A., Karimi, A., Navidbakhsh, M., Ahmadi, H., 2016. Experimental/numerical study to assess mechanical properties of healthy and Marfan syndrome ascending thoracic aorta under axial and circumferential loading. Materials Technology 31, 247-254.

Jeffrey, J.E., Aspden, R.M., 2006. The biophysical effects of a single impact load on human and bovine articular cartilage. Proceedings of the Institution of Mechanical Engineers, Part H: Journal of Engineering in Medicine 220, 677-686. 
Jia, W., Gungor-Ozkerim, P.S., Zhang, Y.S., Yue, K., Zhu, K., Liu, W., Pi, Q., Byambaa, B., Dokmeci, M.R., Shin, S.R., 2016. Direct 3D bioprinting of perfusable vascular constructs using a blend bioink. Biomaterials 106, 58-68.

Jiang, R., Kleer, R., Piller, F.T., 2017. Predicting the future of additive manufacturing: A Delphi study on economic and societal implications of 3D printing for 2030. Technological Forecasting and Social Change 117, 84-97.

Jones, N., 2012. Science in three dimensions: the print revolution. Nature News 487, 22. Juszczyk, M., Cristofolini, L., Kaniuk, J., Schileo, E., Viceconti, M., 2010. A novel method for determining the time and location of abrupt fracture initiation in bones. The Journal of Strain Analysis for Engineering Design 45, 481-493.

Kalita, S.J., Bose, S., Hosick, H.L., Bandyopadhyay, A., 2003. Development of controlled porosity polymer-ceramic composite scaffolds via fused deposition modeling. Materials Science and Engineering: C 23, 611-620.

Karimi, A., Navidbakhsh, M., Shojaei, A., Faghihi, S., 2013. Measurement of the uniaxial mechanical properties of healthy and atherosclerotic human coronary arteries. Materials Science and Engineering: C 33, 2550-2554.

Karimi, A., Sera, T., Kudo, S., Navidbakhsh, M., 2016. Experimental verification of the healthy and atherosclerotic coronary arteries incompressibility via digital image correlation. Artery Research 16, $1-7$.

Katsumura, M., HIRATSUKA, T., Fushimi, H., Ishii, Y., OKAMURA, A., Ota, H., Arakawa, J., 2019. Method for producing gelatin formed body and gelatin formed body. Google Patents.

Kawasaki, T., Sasayama, S., Yagi, S.-I., Asakawa, T., Hirai, T., 1987. Non-invasive assessment of the age related changes in stiffness of major branches of the human arteries. Cardiovascular research 21, 678-687.

Ke, D., Bose, S., 2018. Effects of pore distribution and chemistry on physical, mechanical, and biological properties of tricalcium phosphate scaffolds by binder-jet 3D printing. Additive Manufacturing 22, 111-117.

Keaveny, T.M., Buckley, J.M., 2006. Biomechanics of vertebral bone. Spine technology handbook, 63-98.

Kelly, C.N., Evans, N.T., Irvin, C.W., Chapman, S.C., Gall, K., Safranski, D.L., 2019. The effect of surface topography and porosity on the tensile fatigue of 3D printed Ti-6Al-4V fabricated by selective laser melting. Materials Science \& Engineering C-Materials for Biological Applications 98, 726-736. Khalil, S., Sun, W., 2007. Biopolymer deposition for freeform fabrication of hydrogel tissue constructs. Materials Science and Engineering: C 27, 469-478.

Kim, S.H., Yeon, Y.K., Lee, J.M., Chao, J.R., Lee, Y.J., Seo, Y.B., Sultan, M.T., Lee, O.J., Lee, J.S., Yoon, S.-i., 2018. Precisely printable and biocompatible silk fibroin bioink for digital light processing 3D printing. Nature communications 9, 1620.

Kopperdahl, D.L., Keaveny, T.M., 1998. Yield strain behavior of trabecular bone. Journal of biomechanics 31, 601-608.

Kotlarz, M., Jordan, R., Wegner, E., Dobrzyński, P., Neunzehn, J., Lederer, A., Wolf-Brandstetter, C., Pamula, E., Scharnweber, D., 2018. One step 3D printing of surface functionalized composite scaffolds for tissue engineering applications. Acta of bioengineering and biomechanics 20.

Kranz, J., Herzog, D., Emmelmann, C., 2015. Design guidelines for laser additive manufacturing of lightweight structures in TiA16V4. J Laser Appl 27, S14001.

Kruth, J.-P., Wang, X., Laoui, T., Froyen, L., 2003. Lasers and materials in selective laser sintering. Assembly Automation 23, 357-371.

Kural, M.H., Cai, M., Tang, D., Gwyther, T., Zheng, J., Billiar, K.L., 2012. Planar biaxial characterization of diseased human coronary and carotid arteries for computational modeling. Journal of biomechanics 45, 790-798.

Lafond, D., Prince, F., 2004. Obesity and knee joint torque and power during level walking. Journal of biomechanics 10, 1631-1632.

Lally, C., Reid, A., Prendergast, P.J., 2004. Elastic behavior of porcine coronary artery tissue under uniaxial and equibiaxial tension. Annals of biomedical engineering 32, 1355-1364.

Lam, C.X.F., Mo, X., Teoh, S.-H., Hutmacher, D., 2002. Scaffold development using 3D printing with a starch-based polymer. Materials Science and Engineering: C 20, 49-56. 
Lanzarone, E., Marconi, S., Conti, M., Auricchio, F., Fassi, I., Modica, F., Pagano, C., Pourabdollahian, G., 2019. Hospital Factory for Manufacturing Customised, Patient-Specific 3D Anatomo-Functional Models and Prostheses, in: Tolio, T., Copani, G., Terkaj, W. (Eds.), Factories of the Future: The Italian Flagship Initiative. Springer International Publishing, Cham, pp. 233-254. Lavecchia, C., Espino, D., Moerman, K., Tse, K., Robinson, D., Lee, P., Shepherd, D., 2018. Lumbar model generator: a tool for the automated generation of a parametric scalable model of the lumbar spine. Journal of The Royal Society Interface 15, 20170829.

Lawless, B.M., Sadeghi, H., Temple, D.K., Dhaliwal, H., Espino, D.M., Hukins, D.W., 2017. Viscoelasticity of articular cartilage: analysing the effect of induced stress and the restraint of bone in a dynamic environment. Journal of the mechanical behavior of biomedical materials 75, 293-301. Learoyd, B.M., Taylor, M.G., 1966. Alterations with age in the viscoelastic properties of human arterial walls. Circulation research 18, 278-292.

Lee, J.-Y., An, J., Chua, C.K., 2017. Fundamentals and applications of 3D printing for novel materials. Applied Materials Today 7, 120-133.

Lee, J.S., Cha, H.D., Shim, J.H., Jung, J.W., Kim, J.Y., Cho, D.W., 2012. Effect of pore architecture and stacking direction on mechanical properties of solid freeform fabrication-based scaffold for bone tissue engineering. Journal of Biomedical Materials Research Part A 100, 1846-1853.

Lee, K.-W., Wang, S., Fox, B.C., Ritman, E.L., Yaszemski, M.J., Lu, L., 2007. Poly (propylene fumarate) bone tissue engineering scaffold fabrication using stereolithography: effects of resin formulations and laser parameters. Biomacromolecules 8, 1077-1084.

Lee, S.-J., Kang, H.-W., Park, J.K., Rhie, J.-W., Hahn, S.K., Cho, D.-W., 2008. Application of microstereolithography in the development of three-dimensional cartilage regeneration scaffolds. Biomedical microdevices 10, 233-241.

Lei, M., Wang, X., 2016. Biodegradable polymers and stem cells for bioprinting. Molecules 21, 539. Li, J.J., Zreiqat, H., 2019. Tissue Response to Biomaterials, in: Narayan, R. (Ed.), Encyclopedia of Biomedical Engineering, pp. 270-277.

Liao, J., Smith, D.W., Miramini, S., Thibbotuwawa, N., Gardiner, B.S., Zhang, L., 2019. The investigation of fluid flow in cartilage contact gap. Journal of the mechanical behavior of biomedical materials 95, 153-164.

Liao, J., Vesely, I., 2003. A structural basis for the size-related mechanical properties of mitral valve chordae tendineae. Journal of biomechanics 36, 1125-1133.

Lim, K.S., Levato, R., Costa, P.F., Castilho, M.D., Alcala-Orozco, C.R., van Dorenmalen, K.M., Melchels, F.P., Gawlitta, D., Hooper, G.J., Malda, J., 2018. Bio-resin for high resolution lithographybased biofabrication of complex cell-laden constructs. Biofabrication 10, 034101.

Linzhong, Z., Lian, Q., You, L., Weiguo, B., Dichen, L., Zhongmin, J., 2010. The Research of Technique on Fabricating Hydrogel Scaffolds for Cartilage Tissue Engineering Based on Stereolithography.

Liu, J., Sun, L., Xu, W., Wang, Q., Yu, S., Sun, J., 2018. Current advances and future perspectives of 3D printing natural-derived biopolymers. Carbohydrate polymers.

Liu, Y., Zhang, Y., Jiang, W., Peng, Y., Luo, J., Xie, S., Zhong, S., Pu, H., Liu, N., Yue, T., 2019a. A Novel Biodegradable Multilayered Bioengineered Vascular Construct with a Curved Structure and Multi-Branches. Micromachines 10, 275.

Liu, Z.B., Liang, H.X., Shi, T.S., Xie, D.Q., Chen, R.Y., Han, X., Shen, L.D., Wang, C.J., Tian, Z.J., $2019 \mathrm{~b}$. Additive manufacturing of hydroxyapatite bone scaffolds via digital light processing and in vitro compatibility. Ceramics International 45, 11079-11086.

Longley, R., Ferreira, A.M., Gentile, P., 2018. Recent Approaches to the Manufacturing of Biomimetic Multi-Phasic Scaffolds for Osteochondral Regeneration. International Journal of Molecular Sciences 19.

Longmore, R.B., Gardner, D.L., 1975. Development with age of human articular cartilage surface structure. A survey by interference microscopy of the lateral femoral condyle. Annals of the Rheumatic Diseases 34, 26-37.

Lowe, J., Anderson, P., 1997. Human Histology, 2nd ed. Mosby Ltd., London.

Lucas, G.L., Cooke, F.W., Friis, E.A., 1999. Tissue mechanics, A Primer of Biomechanics. Springer, pp. 257-280. 
Magin, C.M., Alge, D.L., Anseth, K.S., 2016. Bio-inspired 3D microenvironments: a new dimension in tissue engineering. Biomedical Materials 11.

Mahbod, M., Asgari, M., 2019. Elastic and plastic characterization of a new developed additively manufactured functionally graded porous lattice structure: Analytical and numerical models.

International Journal of Mechanical Sciences 155, 248-266.

Malda, J., Visser, J., Melchels, F.P., Jüngst, T., Hennink, W.E., Dhert, W.J., Groll, J., Hutmacher, D.W., 2013. 25th anniversary article: engineering hydrogels for biofabrication. Advanced materials 25, 5011-5028.

Malik, I.A., Mirkhalaf, M., Barthelat, F., 2017. Bio-inspired "jigsaw"-like interlocking sutures: Modeling, optimization, 3D printing and testing. Journal of the Mechanics and Physics of Solids 102, 224-238.

Martin, V., Bettencourt, A., 2018. Bone regeneration: Biomaterials as local delivery systems with improved osteoinductive properties. Materials Science and Engineering: C 82, 363-371.

Martins, P., Natal Jorge, R., Ferreira, A., 2006. A comparative study of several material models for prediction of hyperelastic properties: Application to silicone-rubber and soft tissues. Strain 42, 135 147.

Mathews, M.B., Decker, L., 1977. Comparative studies of water sorption of hyaline cartilage.

Biochimica et Biophysica Acta (BBA)-General Subjects 497, 151-159.

Matsuzaki, R., Ueda, M., Namiki, M., Jeong, T.-K., Asahara, H., Horiguchi, K., Nakamura, T., Todoroki, A., Hirano, Y., 2016. Three-dimensional printing of continuous-fiber composites by innozzle impregnation. Scientific reports 6, 23058.

Mazza, E., Ehret, A.E., 2015. Mechanical biocompatibility of highly deformable biomedical materials. Journal of the mechanical behavior of biomedical materials 48, 100-124.

Mazzoli, A., 2013. Selective laser sintering in biomedical engineering. Medical \& biological engineering \& computing 51, 245-256.

Meakin, J.R., Hukins, D., Imrie, C., Aspden, R.M., 2003. Thermal analysis of poly (2-hydroxyethyl methacrylate)(pHEMA) hydrogels. Journal of Materials Science: Materials in Medicine 14, 9-15.

Meisel, N., Williams, C., 2015. An Investigation of Key Design for Additive Manufacturing Constraints in Multimaterial Three-Dimensional Printing. Journal of Mechanical Design 137.

Melchels, F.P., Bertoldi, K., Gabbrielli, R., Velders, A.H., Feijen, J., Grijpma, D.W., 2010a.

Mathematically defined tissue engineering scaffold architectures prepared by stereolithography.

Biomaterials 31, 6909-6916.

Melchels, F.P., Dhert, W.J., Hutmacher, D.W., Malda, J., 2014. Development and characterisation of a new bioink for additive tissue manufacturing. Journal of Materials Chemistry B 2, 2282-2289.

Melchels, F.P., Domingos, M.A., Klein, T.J., Malda, J., Bartolo, P.J., Hutmacher, D.W., 2012.

Additive manufacturing of tissues and organs. Progress in Polymer Science 37, 1079-1104.

Melchels, F.P., Feijen, J., Grijpma, D.W., 2010b. A review on stereolithography and its applications in biomedical engineering. Biomaterials 31, 6121-6130.

Memic, A., Navaei, A., Mirani, B., Cordova, J.A.V., Aldhahri, M., Dolatshahi-Pirouz, A., Akbari, M., Nikkhah, M.J.B.L., 2017. Bioprinting technologies for disease modeling. 39, 1279-1290.

Miar, S., Shafiee, A., Guda, T., Narayan, R., 2018. Additive Manufacturing for Tissue Engineering. 3D Printing and Biofabrication, 3-54.

Milentijevic, D., Rubel, I.F., Liew, A.S., Helfet, D.L., Torzilli, P.A., 2005. An in vivo rabbit model for cartilage trauma: a preliminary study of the influence of impact stress magnitude on chondrocyte death and matrix damage. Journal of orthopaedic trauma 19, 466-473.

Milentijevic, D., Torzilli, P.A., 2005. Influence of stress rate on water loss, matrix deformation and chondrocyte viability in impacted articular cartilage. Journal of biomechanics 38, 493-502.

Millington-Sanders, C., Meir, A., Lawrence, L., Stolinski, C., 1998. Structure of chordae tendineae in the left ventricle of the human heart. The Journal of Anatomy 192, 573-581.

Miramini, S., Smith, D.W., Zhang, L., Gardiner, B.S., 2017. The spatio-temporal mechanical environment of healthy and injured human cartilage during sustained activity and its role in cartilage damage. Journal of the Mechanical Behavior of Biomedical Materials.

Miramini, S., Yang, Y., 2019. A probabilistic-based approach for computational simulation of bone fracture healing. Comput. Methods Programs Biomed., 105011. 
Miramini, S., Zhang, L., Richardson, M., Mendis, P., 2018. The Role of Locking Plate Stiffness in Bone Fracture Healing Stabilized by Far Cortical Locking Technique. International Journal of Computational Methods 15, 1850024.

Miramini, S., Zhang, L., Richardson, M., Mendis, P., Ebeling, P.R., 2016a. Influence of fracture geometry on bone healing under locking plate fixations: A comparison between oblique and transverse tibial fractures. Medical Engineering \& Physics 38, 1100-1108.

Miramini, S., Zhang, L., Richardson, M., Mendis, P., Oloyede, A., Ebeling, P., 2016b. The relationship between interfragmentary movement and cell differentiation in early fracture healing under locking plate fixation. Australasian Physical \& Engineering Sciences in Medicine 39, 123-133. Miramini, S., Zhang, L., Richardson, M., Pirpiris, M., Mendis, P., Oloyede, K., Edwards, G., 2015. Computational simulation of the early stage of bone healing under different configurations of locking compression plates. Computer methods in biomechanics and biomedical engineering 18, 900-913. Miramini, S., Zhang, L.H., Richardson, M., Mendis, P., 2014. Computational Simulation of Mechanical Microenvironment of Early Stage of Bone Healing under Locking Compression Plate with Dynamic Locking Screws. Applied Mechanics and Materials 553, 281-286.

Mirkhalaf, M., Barthelat, F., 2017. Design, 3D printing and testing of architectured materials with bistable interlocks. Extreme Mechanics Letters 11, 1-7.

Misof, K., Rapp, G., Fratzl, P., 1997. A new molecular model for collagen elasticity based on synchrotron X-ray scattering evidence. Biophysical journal 72, 1376-1381.

Misra, S., Ramesh, K., Okamura, A.M., 2010. Modelling of non-linear elastic tissues for surgical simulation. Computer methods in biomechanics and biomedical engineering 13, 811-818.

Mitchell, S.L., Niklason, L.E., 2003. Requirements for growing tissue-engineered vascular grafts. Cardiovascular Pathology 12, 59-64.

Mohamed, O.A., Masood, S.H., Bhowmik, J.L., 2015. Optimization of fused deposition modeling process parameters: a review of current research and future prospects. Advances in Manufacturing 3, 42-53.

Mohan, D., Melvin, J.W., 1982. Failure properties of passive human aortic tissue. I-uniaxial tension tests. Journal of biomechanics 15, 887-902.

Mohan, D., Melvin, J.W., 1983. Failure properties of passive human aortic tissue. II-Biaxial tension tests. Journal of Biomechanics 16, 31-44.

Morrison, R.J., Kashlan, K.N., Flanangan, C.L., Wright, J.K., Green, G.E., Hollister, S.J., Weatherwax, K.J., 2015. Regulatory Considerations in the Design and Manufacturing of Implantable 3D-Printed Medical Devices. 8, 594-600.

Mostafaei, A., Stevens, E.L., Ference, J.J., Schmidt, D.E., Chmielus, M., 2018. Binder jetting of a complex-shaped metal partial denture framework. Additive Manufacturing 21, 63-68.

MOZERSKY, D.J., SUMNFR, D.S., HOKANSON, D.E., STRANDNESS JR, D.E., 1972.

Transcutaneous measurement of the elastic properties of the human femoral artery. Circulation 46, 948-955.

Murphy, S.V., Atala, A., 2014a. 3D bioprinting of tissues and organs. Nat Biotechnol 32, 773-785.

Murphy, S.V., Atala, A., 2014b. 3D bioprinting of tissues and organs. Nature biotechnology 32, 773. Murphy, S.V., Skardal, A., Atala, A., 2013. Evaluation of hydrogels for bio-printing applications. Journal of Biomedical Materials Research Part A 101, 272-284.

Narayan, R., 2018. Encyclopedia of Biomedical Engineering Elsevier

Nazarian, A., Stauber, M., Zurakowski, D., Snyder, B.D., Müller, R., 2006. The interaction of microstructure and volume fraction in predicting failure in cancellous bone. Bone 39, 1196-1202.

Ngo, T.D., Kashani, A., Imbalzano, G., Nguyen, K.T., Hui, D., 2018. Additive manufacturing (3D printing): A review of materials, methods, applications and challenges. Composites Part B: Engineering 143, 172-196.

Noor, N., Shapira, A., Edri, R., Gal, I., Wertheim, L., Dvir, T., 2019. 3D Printing of Personalized Thick and Perfusable Cardiac Patches and Hearts. Advanced Science, 1900344.

Novitskaya, E., Chen, P.-Y., Hamed, E., Li, J., Lubarda, V.A., Jasiuk, I., McKittrick, J., 2011. Recent advances on the measurement and calculation of the elastic moduli of cortical and trabecular bone: a review. Theor Appl Mech 38, 209-297. 
O'Leary, S.A., Doyle, B.J., McGloughlin, T.M., 2014. The impact of long term freezing on the mechanical properties of porcine aortic tissue. Journal of the mechanical behavior of biomedical materials 37, 165-173.

Odde, D.J., Renn, M.J., 1999. Laser-guided direct writing for applications in biotechnology. Trends in biotechnology 17, 385-389.

Öhman, C., Baleani, M., Pani, C., Taddei, F., Alberghini, M., Viceconti, M., Manfrini, M., 2011.

Compressive behaviour of child and adult cortical bone. Bone 49, 769-776.

Oladapo, B.I., Zahedi, S.A., Adeoye, A.O.M., 2019. 3D printing of bone scaffolds with hybrid biomaterials. Composites Part B-Engineering 158, 428-436.

Ombregt, L., 2013. A System of Orthopaedic Medicine, 3rd Edition. Churchill Livingstone Elsevier. Onofrillo, C., Duchi, S., O'Connell, C.D., Blanchard, R., O'Connor, A.J., Scott, M., Wallace, G.G., Choong, P.F.M., Di Bella, C., 2018. Biofabrication of human articular cartilage: a path towards the development of a clinical treatment. Biofabrication 10, 045006.

Orr, A.W., Helmke, B.P., Blackman, B.R., Schwartz, M.A., 2006. Mechanisms of mechanotransduction. Developmental cell 10, 11-20.

Ozbolat, I.T., Hospodiuk, M., 2016. Current advances and future perspectives in extrusion-based bioprinting. Biomaterials 76, 321-343.

Ozbolat, I.T., Yu, Y., 2013. Bioprinting toward organ fabrication: challenges and future trends. IEEE Transactions on Biomedical Engineering 60, 691-699.

Ozolanta, I., Tetere, G., Purinya, B., Kasyanov, V., 1998. Changes in the mechanical properties, biochemical contents and wall structure of the human coronary arteries with age and sex. Medical engineering \& physics 20, 523-533.

Pattanayak, D.K., Fukuda, A., Matsushita, T., Takemoto, M., Fujibayashi, S., Sasaki, K., Nishida, N., Nakamura, T., Kokubo, T., 2011. Bioactive Ti metal analogous to human cancellous bone: fabrication by selective laser melting and chemical treatments. Acta Biomaterialia 7, 1398-1406.

Pearson, B., Espino, D.M., 2013. Effect of hydration on the frequency-dependent viscoelastic properties of articular cartilage. Proceedings of the Institution of Mechanical Engineers, Part H: Journal of Engineering in Medicine 227, 1246-1252.

Perilli, E., Baleani, M., Öhman, C., Fognani, R., Baruffaldi, F., Viceconti, M., 2008. Dependence of mechanical compressive strength on local variations in microarchitecture in cancellous bone of proximal human femur. Journal of biomechanics 41, 438-446.

Philbrick, K.A., Wong, C.P., Kahler-Quesada, A.M., Olson, D.A., Branscum, A.J., Turner, R.T., Iwaniec, U.T., 2018. Polyethylene particles inserted over calvarium induce cancellous bone loss in femur in female mice. Bone reports 9, 84-92.

Pilliar, R., Cameron, H., Macnab, I., 1975. Porous surface layered prosthetic devices. Biomedical engineering 10, 126-131.

Pradel, P., Zhu, Z.C., Bibb, R., Moultrie, J., 2018. A framework for mapping design for additive manufacturing knowledge for industrial and product design. Journal of Engineering Design 29, 291 326.

Puxkandl, R., Zizak, I., Paris, O., Keckes, J., Tesch, W., Bernstorff, S., Purslow, P., Fratzl, P., 2002. Viscoelastic properties of collagen: synchrotron radiation investigations and structural model.

Philosophical Transactions of the Royal Society of London. Series B: Biological Sciences 357, 191197.

Ronca, A., Ambrosio, L., Grijpma, D.W., 2013. Preparation of designed poly (D, L-lactide)/nanosized hydroxyapatite composite structures by stereolithography. Acta biomaterialia 9, 5989-5996.

Rosen, D.W., 2007. Design for additive manufacturing: a method to explore unexplored regions of the design space. Proceedings of the Annual International Solid Freeform Fabrication Symposium, 402415.

Rosenzweig, D.H., Carelli, E., Steffen, T., Jarzem, P., Haglund, L., 2015. 3D-Printed ABS and PLA Scaffolds for Cartilage and Nucleus Pulposus Tissue Regeneration. International journal of molecular sciences 16, 15118-15135.

Rowe, R.G., Daley, G.Q., 2019. Induced pluripotent stem cells in disease modelling and drug discovery. Nature Reviews Genetics 20, 377-388.

Roy, A., Saxena, V., Pandey, L.M., 2018. 3D printing for cardiovascular tissue engineering: a review. Materials technology 33, 433-442. 
Sadeghi, H., Espino, D., Shepherd, D., 2017. Fatigue strength of bovine articular cartilage-on-bone under three-point bending: the effect of loading frequency. BMC musculoskeletal disorders 18, 142. Sadeghi, H., Espino, D.M., Shepherd, D.E., 2015a. Variation in viscoelastic properties of bovine articular cartilage below, up to and above healthy gait-relevant loading frequencies. Proceedings of the Institution of Mechanical Engineers, Part H: Journal of Engineering in Medicine 229, 115-123.

Sadeghi, H., Lawless, B.M., Espino, D., Shepherd, D., 2018. Effect of frequency on crack growth in articular cartilage. Journal of the mechanical behavior of biomedical materials 77, 40-46.

Sadeghi, H., Shepherd, D., Espino, D., 2015b. Effect of the variation of loading frequency on surface failure of bovine articular cartilage. Osteoarthritis and cartilage 23, 2252-2258.

Salimi Bani, M., Asgharzadeh Shirazi, H., Ayatollahi, M.R., Asnafi, A.J.M., Engineering, B., Computing, 2017. A new model for the artificial aorta blood vessels using double-sided radial functionally graded biomaterials. 55, 859-871.

Schaffler, M.B., Burr, D.B., 1988. Stiffness of compact bone: effects of porosity and density. Journal of biomechanics 21, 13-16.

Schüller-Ravoo, S., Teixeira, S.M., Feijen, J., Grijpma, D.W., Poot, A.A., 2013. Flexible and Elastic Scaffolds for Cartilage Tissue Engineering Prepared by Stereolithography Using Poly(trimethylene carbonate)-Based Resins. 13, 1711-1719.

Schüller-Ravoo, S., Teixeira, S.M., Feijen, J., Grijpma, D.W., Poot, A.A., 2013. Flexible and Elastic Scaffolds for Cartilage Tissue Engineering Prepared by Stereolithography Using Poly (trimethylene carbonate)-B ased Resins. Macromol. Biosci. 13, 1711-1719.

Schulze-Bauer, C.A., Regitnig, P., Holzapfel, G.A., 2002. Mechanics of the human femoral adventitia including the high-pressure response. American Journal of Physiology-Heart and Circulatory Physiology 282, H2427-H2440.

Seck, T.M., Melchels, F.P., Feijen, J., Grijpma, D.W., 2010. Designed biodegradable hydrogel structures prepared by stereolithography using poly (ethylene glycol)/poly (D, L-lactide)-based resins. J. Control. Release 148, 34-41.

Seedholm, B., Takeda, T., Tsubuku, M., Wright, V., 1979. Mechanical factors and patellofemoral osteoarthrosis. Annals of the Rheumatic Diseases 38, 307-316.

Seitz, H., Rieder, W., Irsen, S., Leukers, B., Tille, C., 2005. Three-dimensional printing of porous ceramic scaffolds for bone tissue engineering. Journal of Biomedical Materials Research Part B: Applied Biomaterials: An Official Journal of The Society for Biomaterials, The Japanese Society for Biomaterials, and The Australian Society for Biomaterials and the Korean Society for Biomaterials 74, $782-788$.

Serra, T., Mateos-Timoneda, M.A., Planell, J.A., Navarro, M., 2013. 3D printed PLA-based scaffolds: a versatile tool in regenerative medicine. Organogenesis 9, 239-244.

Shen, S., Chen, M., Guo, W., Li, H., Li, X., Huang, S., Luo, X., Wang, Z., Wen, Y., Yuan, Z., Zhang, B., Peng, L., Gao, C., Guo, Q., Liu, S., Zhuo, N., 2019. Three Dimensional Printing-Based Strategies for Functional Cartilage Regeneration. Tissue engineering. Part B, Reviews 25, 187-201.

Shepherd, D., Seedhom, B., 1999. The'instantaneous' compressive modulus of human articular cartilage in joints of the lower limb. Rheumatology (Oxford, England) 38, 124-132.

Shi, W., Sun, M., Hu, X., Ren, B., Cheng, J., Li, C., Duan, X., Fu, X., Zhang, J., Chen, H., Ao, Y., 2017. Structurally and Functionally Optimized Silk-Fibroin-Gelatin Scaffold Using 3D Printing to Repair Cartilage Injury In Vitro and In Vivo. Advanced materials (Deerfield Beach, Fla.) 29.

Shim, J.-H., Won, J.-Y., Park, J.-H., Bae, J.-H., Ahn, G., Kim, C.-H., Lim, D.-H., Cho, D.-W., Yun, W.-S., Bae, E.-B., 2017. Effects of 3D-printed polycaprolactone/ $\beta$-tricalcium phosphate membranes on guided bone regeneration. International journal of molecular sciences 18, 899 .

Shor, L., Güçeri, S., Chang, R., Gordon, J., Kang, Q., Hartsock, L., An, Y., Sun, W., 2009. Precision extruding deposition (PED) fabrication of polycaprolactone (PCL) scaffolds for bone tissue engineering. Biofabrication 1, 015003.

Shuang, F., Hu, W., Shao, Y., Li, H., Zou, H., 2016. Treatment of intercondylar humeral fractures with 3D-printed osteosynthesis plates. Medicine 95.

Skardal, A., Zhang, J., McCoard, L., Xu, X., Oottamasathien, S., Prestwich, G.D., 2010.

Photocrosslinkable hyaluronan-gelatin hydrogels for two-step bioprinting. Tissue Engineering Part A $16,2675-2685$. 
Skoog, S.A., Goering, P.L., Narayan, R.J., 2014. Stereolithography in tissue engineering. Journal of Materials Science: Materials in Medicine 25, 845-856.

Soe, S., Eyers, D.R., Setchi, R.J.T.I.J.o.A.M.T., 2013. Assessment of non-uniform shrinkage in the laser sintering of polymer materials. 68, 111-125.

Stansbury, J.W., Idacavage, M.J., 2016. 3D printing with polymers: Challenges among expanding options and opportunities. Dent. Mater. 32, 54-64.

Stecco, C., 2014. Functional Atlas of the Human Fascial System E-Book. Elsevier Health Sciences. Stemper, B.D., Yoganandan, N., Stineman, M.R., Gennarelli, T.A., Baisden, J.L., Pintar, F.A., 2007. Mechanics of fresh, refrigerated, and frozen arterial tissue. Journal of Surgical Research 139, 236 242.

Swann, A., Seedhom, B., 1993. The stiffness of normal articular cartilage and the predominant acting stress levels: implications for the aetiology of osteoarthrosis. Rheumatology 32, 16-25.

Syedain, Z.H., Meier, L.A., Bjork, J.W., Lee, A., Tranquillo, R.T., 2011. Implantable arterial grafts from human fibroblasts and fibrin using a multi-graft pulsed flow-stretch bioreactor with noninvasive strength monitoring. Biomaterials 32, 714-722.

Synopsys, I., 2019. Simpleware Software.

Tavakoli Nia, H., Han, L., Li, Y., Ortiz, C., Grodzinsky, A., 2011. Poroelasticity of Cartilage at the Nanoscale.

Taylor, S.D., Tsiridis, E., Ingham, E., Jin, Z., Fisher, J., Williams, S., 2012. Comparison of human and animal femoral head chondral properties and geometries. Proceedings of the Institution of Mechanical Engineers, Part H: Journal of Engineering in Medicine 226, 55-62.

Terrazas, C.A., Murr, L.E., Bermudez, D., Arrieta, E., Roberson, D.A., Wicker, R.B., 2019. Microstructure and mechanical properties of Ti-6Al-4V-5\% hydroxyapatite composite fabricated using electron beam powder C bed fusion. Journal of Materials Science \& Technology 35, 309-321. Thomas-Seale, L.E.J., Kirkman-Brown, J.C., Attallah, M.M., Espino, D.M., Shepherd, D.E.T., 2018. The barriers to the progression of additive manufacture: perspectives from UK industry. Int J Prod Econ 198, 104-118.

Tomasek, J.J., Gabbiani, G., Hinz, B., Chaponnier, C., Brown, R.A., 2002. Myofibroblasts and mechano-regulation of connective tissue remodelling. Nature reviews Molecular cell biology 3, 349 .

Torres, Y., Trueba, P., Pavon, J.J., Chicardi, E., Kamm, P., Garcia-Moreno, F., Rodriguez-Ortiz, J.A., 2016. Design, processing and characterization of titanium with radial graded porosity for bone implants. Mater. Des. 110, 179-187.

United States Congress, 2011. United States Code: Federal Food, Drug, and Cosmetic Act, Title 21 Food and Drugs, Chapter 9 - Federal Food, Drug, and Cosmetic Act. 21 U.S.C. §§ 301-399 (Suppl. 5 2006).

US Food and Drug Administration, 2014. Custom Device Exemption Guidance for Industry and Food and Drug Administration Staff Public Comment 2014.

Vaezi, M., Black, C., Gibbs, D.M.R., Oreffo, R.O.C., Brady, M., Moshrefi-Torbati, M., Yang, S.F., 2016. Characterization of New PEEK/HA Composites with 3D HA Network Fabricated by Extrusion Freeforming. Molecules 21.

Vaezi, M., Yang, S.F., 2015. Extrusion-based additive manufacturing of PEEK for biomedical applications. Virtual and Physical Prototyping 10, 123-135.

Van Andel, C.J., Pistecky, P.V., Borst, C., 2003. Mechanical properties of porcine and human arteries: implications for coronary anastomotic connectors. The Annals of thoracic surgery 76, 58-64. Vandenbroucke, B., Kruth, J.-P., 2007. Selective laser melting of biocompatible metals for rapid manufacturing of medical parts. Rapid Prototyping Journal 13, 196-203.

Venn, M., 1978. Variation of chemical composition with age in human femoral head cartilage. Annals of the rheumatic diseases 37, 168-174.

Venn, M., Maroudas, A., 1977. Chemical composition and swelling of normal and osteoarthrotic femoral head cartilage. I. Chemical composition. Annals of the rheumatic diseases 36, 121-129. Veress, A., Vince, D., Anderson, P.M., Cornhill, J., Herderick, E., Klingensmith, J., Kuban, B., Greenberg, N., Thomas, J., 2000. Vascular mechanics of the coronary artery. Zeitschrift für Kardiologie 89, S092-S100. 
Vidimce, K., Kaspar, A., Wang, Y., Matusik, W., Acm, 2016. Foundry: Hierarchical material design for multi-material fabrication, Uist 2016: Proceedings of the 29th Annual Symposium on User Interface Software and Technology, pp. 563-574.

Vorp, D.A., Schiro, B.J., Ehrlich, M.P., Juvonen, T.S., Ergin, M.A., Griffith, B.P., 2003. Effect of aneurysm on the tensile strength and biomechanical behavior of the ascending thoracic aorta. The Annals of thoracic surgery 75, 1210-1214.

Wachter, N., Augat, P., Krischak, G., Sarkar, M., Mentzel, M., Kinzl, L., Claes, L., 2001. Prediction of strength of cortical bone in vitro by microcomputed tomography. Clinical Biomechanics 16, 252 256.

Wang, C., Garcia, M., Lu, X., Lanir, Y., Kassab, G.S., 2006. Three-dimensional mechanical properties of porcine coronary arteries: a validated two-layer model. American Journal of PhysiologyHeart and Circulatory Physiology 291, H1200-H1209.

Wang, Y., Hahn, J., Zhang, Y., 2018. Mechanical Properties of Arterial Elastin With Water Loss. Journal of biomechanical engineering 140, 041012.

Webb, B., Doyle, B.J., 2017. Parameter optimization for 3D bioprinting of hydrogels. Bioprinting 8, $8-12$.

Wen, Y., Xun, S., Haoye, M., Baichuan, S., Peng, C., Xuejian, L., Kaihong, Z., Xuan, Y., Jiang, P., Shibi, L., 2017. 3D printed porous ceramic scaffolds for bone tissue engineering: a review.

Biomaterials science 5, 1690-1698.

White, A., 1990. Clinical biomechanics of the spine. Clinical biomechanics of the spine.

Williams, D., 1989. A model for biocompatibility and its evaluation. Journal of biomedical engineering 11, 185-191.

Williams, D.F., 1987. Definitions in biomaterials: progress in biomedical engineering. Biomaterials $10,216-238$.

Williams, D.F., 2019. Biomaterials for Sustainable Tissue Engineering. Frontiers in Bioengineering and Biotechnology 7, 127.

Woodruff, M.A., Hutmacher, D.W., 2010. The return of a forgotten polymer-Polycaprolactone in the 21st century. Progress in Polymer Science 35, 1217-1256.

Wu, Z., Zhao, J., Wu, W., Wang, P., Wang, B., Li, G., Zhang, S., 2018. Radial Compressive Property and the Proof-of-Concept Study for Realizing Self-expansion of 3D Printing Polylactic Acid Vascular Stents with Negative Poisson's Ratio Structure. Materials 11, 1357.

$\mathrm{Xu}, \mathrm{T}$. , Jin, J., Gregory, C., Hickman, J.J., Boland, T., 2005. Inkjet printing of viable mammalian cells. Biomaterials 26, 93-99.

Yang, C., Bach, R.G., Zheng, J., Naqa, I.E., Woodard, P.K., Teng, Z., Billiar, K., Tang, D., 2009. In VivoIVUS-Based 3-D Fluid-Structure Interaction Models With Cyclic Bending and Anisotropic Vessel Properties for Human Atherosclerotic Coronary Plaque Mechanical Analysis. IEEE Transactions on Biomedical Engineering 56, 2420-2428.

Yang, E., Miao, S., Zhong, J., Zhang, Z., Mills, D.K., Zhang, L.G., 2018. Bio-based polymers for 3D printing of bioscaffolds. Polymer Reviews 58, 668-687.

Yap, C.Y., Chua, C.K., Dong, Z.L., Liu, Z.H., Zhang, D.Q., Loh, L.E., Sing, S.L., 2015. Review of selective laser melting: Materials and applications. Applied physics reviews 2, 041101.

Yoder, J.H., Elliott, D.M., 2010. Nonlinear and anisotropic tensile properties of graft materials used in soft tissue applications. Clinical biomechanics 25, 378-382.

You, F., Eames, B.F., Chen, X., 2017. Application of extrusion-based hydrogel bioprinting for cartilage tissue engineering. International journal of molecular sciences 18, 1597.

Zeng, Y., Yan, Y., Yan, H., Liu, C., Li, P., Dong, P., Zhao, Y., Chen, J., 2018. 3D printing of hydroxyapatite scaffolds with good mechanical and biocompatible properties by digital light processing. Journal of materials science 53, 6291-6301.

Zhang ${ }^{1}$, L., Miramini, S., Mendis, P., Richardson, M., Pirpiris, M., Oloyede, K., 2013. The effects of flexible fixation on early stage bone fracture healing. International Journal of Aerospace and Lightweight Structures 3, 181-189.

Zhang, B., Pei, X., Song, P., Sun, H., Li, H., Fan, Y., Jiang, Q., Zhou, C., Zhang, X., 2018. Porous bioceramics produced by inkjet 3D printing: Effect of printing ink formulation on the ceramic macro and micro porous architectures control. Composites Part B: Engineering 155, 112-121. 
Zhang, H., Zhou, L., Zhang, W., 2014. Control of scaffold degradation in tissue engineering: a review. Tissue Engineering Part B: Reviews 20, 492-502.

Zhang, L., Gardiner, B.S., Smith, D.W., Pivonka, P., Grodzinsky, A., 2008. A fully coupled poroelastic reactive-transport model of cartilage. Molecular and Cellular Biomechanics 5, 133. Zhang, L., Miramini, S., Gardiner, B.S., Smith, D.W., Grodzinsky, A.J., 2015. Time evolution of deformation in a human cartilage under cyclic loading. Annals of Biomedical Engineering 43, 11661177.

Zhang, L., Miramini, S., Richardson, M., Ebeling, P., Little, D., Yang, Y., Huang, Z., 2017 a.

Computational modelling of bone fracture healing under partial weight-bearing exercise. Medical Engineering \& Physics 42, 65-72.

Zhang, L., Miramini, S., Richardson, M., Mendis, P., Ebeling, P., 2017b. The role of impairment of mesenchymal stem cell function in osteoporotic bone fracture healing. Australas. Phys. Eng. Sci.

Med., 1-8.

Zhang, X., Jiang, X., Sun, C., 1999. Micro-stereolithography of polymeric and ceramic microstructures. Sensors and Actuators A: Physical 77, 149-156.

Zhang, X.Y., Fang, G., Leeflang, S., Zadpoor, A.A., Zhou, J., 2019. Topological design, permeability and mechanical behavior of additively manufactured functionally graded porous metallic biomaterials. Acta Biomaterialia 84, 437-452. 